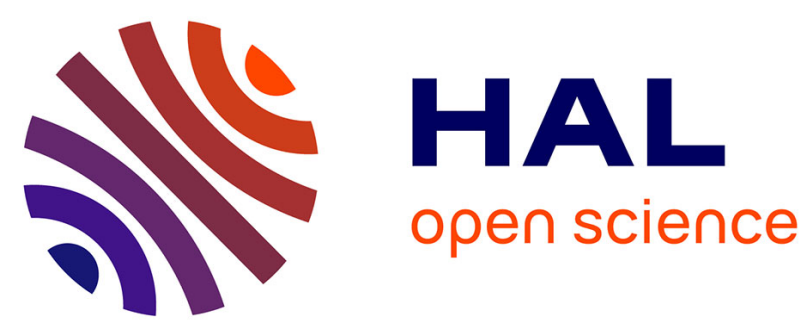

\title{
The 1905 Chamonix earthquakes: active tectonics in the Mont Blanc and Aiguilles Rouges massifs
}

Michel Cara, Jerome van Der Woerd, Pierre-Jean Alasset, Juan Benjumea, Anne-Sophie Meriaux

\section{- To cite this version:}

Michel Cara, Jerome van Der Woerd, Pierre-Jean Alasset, Juan Benjumea, Anne-Sophie Meriaux. The 1905 Chamonix earthquakes: active tectonics in the Mont Blanc and Aiguilles Rouges massifs. Swiss Journal of Geosciences, 2017, 110 (2), pp.631 - 651. 10.1007/s00015-017-0262-7 . hal-01614540

\author{
HAL Id: hal-01614540 \\ https://hal.science/hal-01614540
}

Submitted on 23 Nov 2021

HAL is a multi-disciplinary open access archive for the deposit and dissemination of scientific research documents, whether they are published or not. The documents may come from teaching and research institutions in France or abroad, or from public or private research centers.
L'archive ouverte pluridisciplinaire HAL, est destinée au dépôt et à la diffusion de documents scientifiques de niveau recherche, publiés ou non, émanant des établissements d'enseignement et de recherche français ou étrangers, des laboratoires publics ou privés.

\section{(c)(1)}

Distributed under a Creative Commons Attribution| 4.0 International License 


\title{
The 1905 Chamonix earthquakes: active tectonics in the Mont Blanc and Aiguilles Rouges massifs
}

\author{
Michel Cara $^{1} \cdot J^{\prime}$ rôme Van der Woerd ${ }^{1} \cdot$ Pierre-Jean Alasset $^{2} \cdot$ Juan Benjumea $^{1}$. \\ Anne-Sophie Mériaux ${ }^{3}$
}

Received: 9 August 2016/ Accepted: 17 January 2017/Published online: 2 February 2017

(C) Swiss Geological Society 2017

\begin{abstract}
Linking earthquakes of moderate size to known tectonic sources is a challenge for seismic hazard studies in northwestern Europe because of overall low strain rates. Here we present a combined study of macroseismic information, tectonic observations, and seismic waveform modelling to document the largest instrumentally known event in the French northern Alps, the April 29, 1905, Chamonix earthquake. The moment magnitude of this event is estimated at $M_{w} 5.3 \pm 0.3$ from records in Göttingen (Germany) and Uppsala (Sweden). The event of April 29 was followed by several afterschocks and in particular a second broadly felt earthquake on August 13, 1905. Macroseismic investigations allow us to favour a location of the epicentres 5-10 km N-NE of Chamonix. Tectonic analysis shows that potentially one amongst several faults might have been activated in 1905. Among them the right lateral strike-slip fault responsible for the recent $2005 \mathrm{M}_{\mathrm{w}}=4.4$ Vallorcine earthquake and a quasinormal fault northeast of the Aiguilles Rouges massif are the most likely candidates. Discussion of tectonic, macroseismic, and instrumental data favour the normal fault hypothesis for the 1905 Chamonix earthquake sequence.
\end{abstract}

Keywords Earthquake $\cdot$ Alps $\cdot$ Tectonics $\cdot$ Seismology

Editorial handling: S. Schmid.

Michel Cara

michel.cara@unistra.fr

1 Université de Strasbourg, EOST-UMR7516, 5 rue R. Descartes, 67084 Strasbourg Cedex, France

2 C-Core, 400 March Road, Suite 210, Ottawa, ON K2K 3H4, Canada

3 School of Geography, Politics and Sociology, Newcastle University, Newcastle upon Tyne, UK

\section{Introduction}

The northwestern Alps are one of the most seismically active regions of France and Switzerland. In the Valais canton, several earthquakes of magnitude $\approx 6$ caused serious damages over the past centuries (e.g. Fäh et al. 2012). Together with the Basel area, this is the region where seismic hazard is highest in Switzerland. Similarly in the new French seismic regulation code, the neighbouring Haute-Savoie is set at the highest seismic hazard level of metropolitan France (Plan-séisme 2015). These levels of seismic hazard are mainly estimated from statistical analysis of instrumental and historical seismicity. Due to a somewhat low to moderate seismicity in these regions as compared with the seismically more active southern Europe, there are very few joint analyses of earthquakes based on both instrumental and tectonic observations in the northwestern Alps. The main purpose of this paper is to present such a joint analysis focused on the largest instrumentally known earthquake in the French northern Alps, the Chamonix 1905 April 29 earthquake (Fig. 1). Its published moment magnitude $\mathrm{M}_{\mathrm{w}}$ ranges between 5.1 and 5.6 (Bernardi et al. 2005; Alasset 2005; Cara et al. 2008; Fäh et al. 2011; Rovida et al. 2011).

The largest instrumentally known earthquake in the nearby Valais canton occurred near Sierre on January 25, 1946, $60 \mathrm{~km}$ northeast of Chamonix (Fig. 1). Its magnitude ranges between $\mathrm{Mw}=5.8$ (Bernardi et al. 2005) and $\mathrm{M}_{\mathrm{w}}=6.1$ (Fritsche and Fäh 2009). More recently, on July 15, 1996 a slightly damaging earthquake struck the city of Annecy, France, $60 \mathrm{~km}$ west of Chamonix (Thouvenot et al. 1998; $\mathrm{M}_{\mathrm{w}}=4.7$ SI-Hex 2014). Within a $30 \mathrm{~km}$ distance from Chamonix, two similar magnitude events are instrumentally recorded: an earthquake near Martigny on August 25, $1915\left(\mathrm{M}_{\mathrm{w}}=4.6\right.$, Bernardi et al. 2005) and 


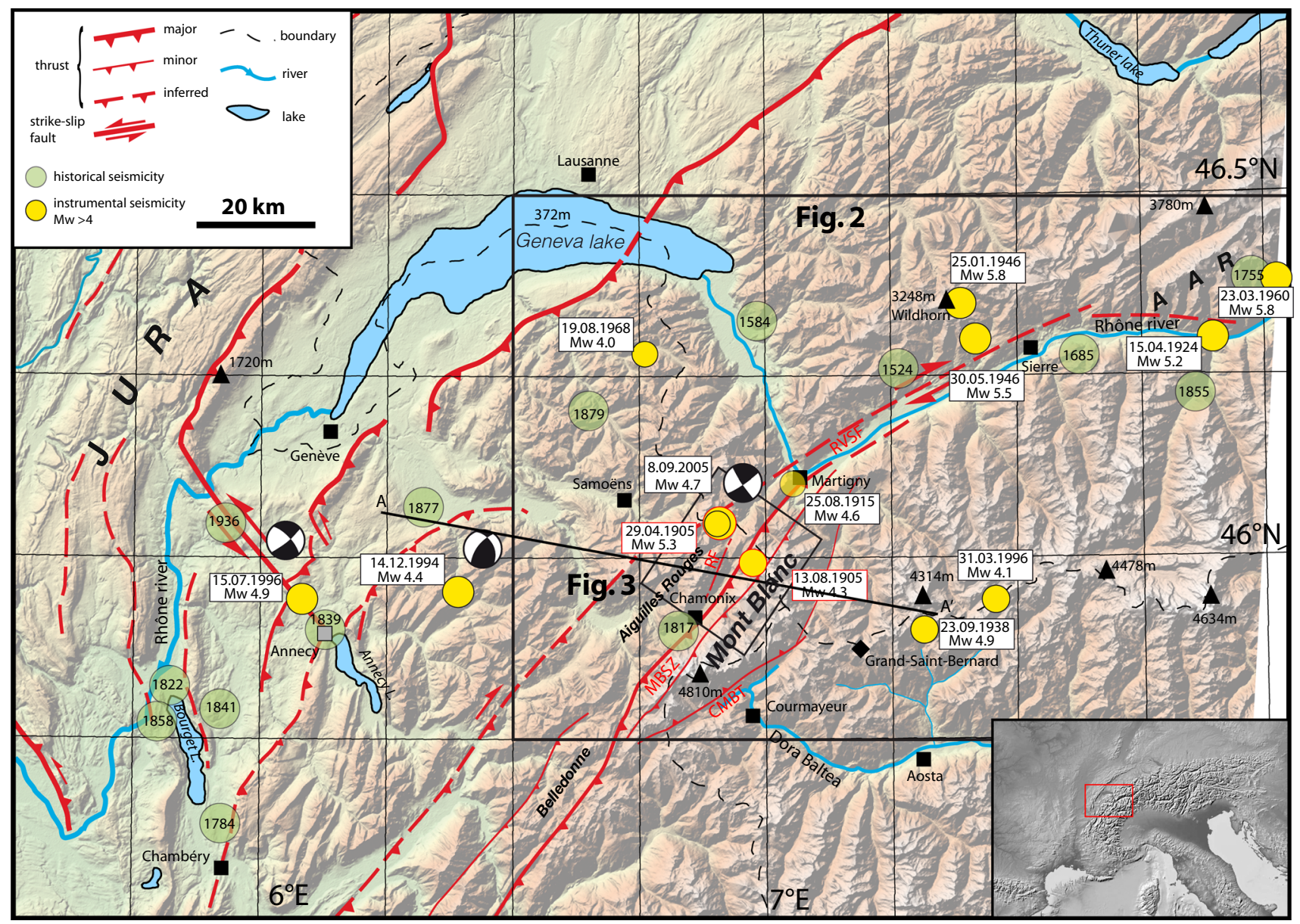

Fig. 1 Seismotectonic map of the northwestern part of the Alps near the Mont Blanc massif. Main active faults from Thouvenot et al. (1998, 2003), Leloup et al. (2005), Armijo et al. (1986). Epicentres of major events from SisFrance (2016) and ECOS-09 (2011). Green; macroseismic pre-instrumental and yellow instrumental $\left(\mathrm{M}_{\mathrm{w}}\right.$ from SIHex, 2014; ECOS, 2011; and Rovida et al. 2011). 1996 and 1994

farther east near the border between the Valais canton in Switzerland and the Aosta county in Italy on September 23, $1938\left(\mathrm{M}_{\mathrm{w}}=4.9\right.$, Rovida et al. $2011 ; \mathrm{M}_{\mathrm{w}}=4$, Fäh et al. 2011). More recently, on September 8, 2005, at proximity to the SisFrance (2016) macroseismic epicentre of the April 291905 Chamonix earthquake, another earthquake occurred near the locality of Vallorcine, France (E3 in Fig. 3) with $\mathrm{M}_{\mathrm{w}}=4.5 \pm 0.1$ (Fréchet et al. 2011; $\mathrm{M}_{\mathrm{w}}=4.4 \pm 0.1$, Rovida et al. $2011 ; \mathrm{M}_{\mathrm{w}}=4.7 \pm 0.2$, SIHex 2014). The microseismic activity of the area is shown in Fig. 2 that displays instrumental data for the period 1984-2008 (ECOS-09; Fäh et al. 2011); note the alignment of micro-earthquakes along the Rhône valley-Salvan Fault zone (RVSF).

The recent 2005 Vallorcine earthquake located at the SW end of the RVSF line drawn in Fig. 2 revealed a right-lateral motion along a sub-vertical fault striking $\mathrm{N} 60^{\circ} \mathrm{E}$ (Fréchet et al. 2011). In 2001, a swarm of small earthquakes $\left(M_{w} \leq 3.6\right)$ focal mechanisms are from Thouvenot et al. (1998) and Fréchet et al. (1996), respectively. Mechanism for the 2005 event is from Fréchet al. (2011). RVSF: Rhône Valley-Salvan Fault or Vallorcine-Valais shear zone; RF : Remuaz Fault; MBSZ: Mont Blanc Shear Zone CMBT: Courmayeur-Mont Blanc Back Thrust. AA': cross-section line of Fig. 6

occurred near the city of Martigny $15 \mathrm{~km}$ northeast of Vallorcine, close to the 1915 Martigny earthquake location. A set of fault segments striking $\approx \mathrm{N} 50^{\circ} \mathrm{E}$ was activated with a right lateral motion in 2001 (Deichmann et al. 2002). Delacou et al. (2005) propose that there is an «exclusively dextral transcurrent regime of deformation» within a series of faults striking parallel to the external crystalline massifs along a line "Wildhorn-Martigny" (RVSF, in Fig. 1). The 2005 Vallorcine earthquake fits well into this scheme. This interpretation may also be compatible with the general NW-SE directed compression scenario of the Mont Blanc and Aiguilles Rouges massifs advocated by Leloup et al. (2005) if we consider a transpressive regime. Dextral strike slip deformation within the Mont Blanc shear zone could still be active today (Egli and Mancktelow 2013). It could have been active, but in an overall thrust regime, either since $16 \mathrm{Ma}$ until present, following Rolland et al. (2007) or only between 12 and 4 Ma, following Leloup et al. $(2005,2007)$. 


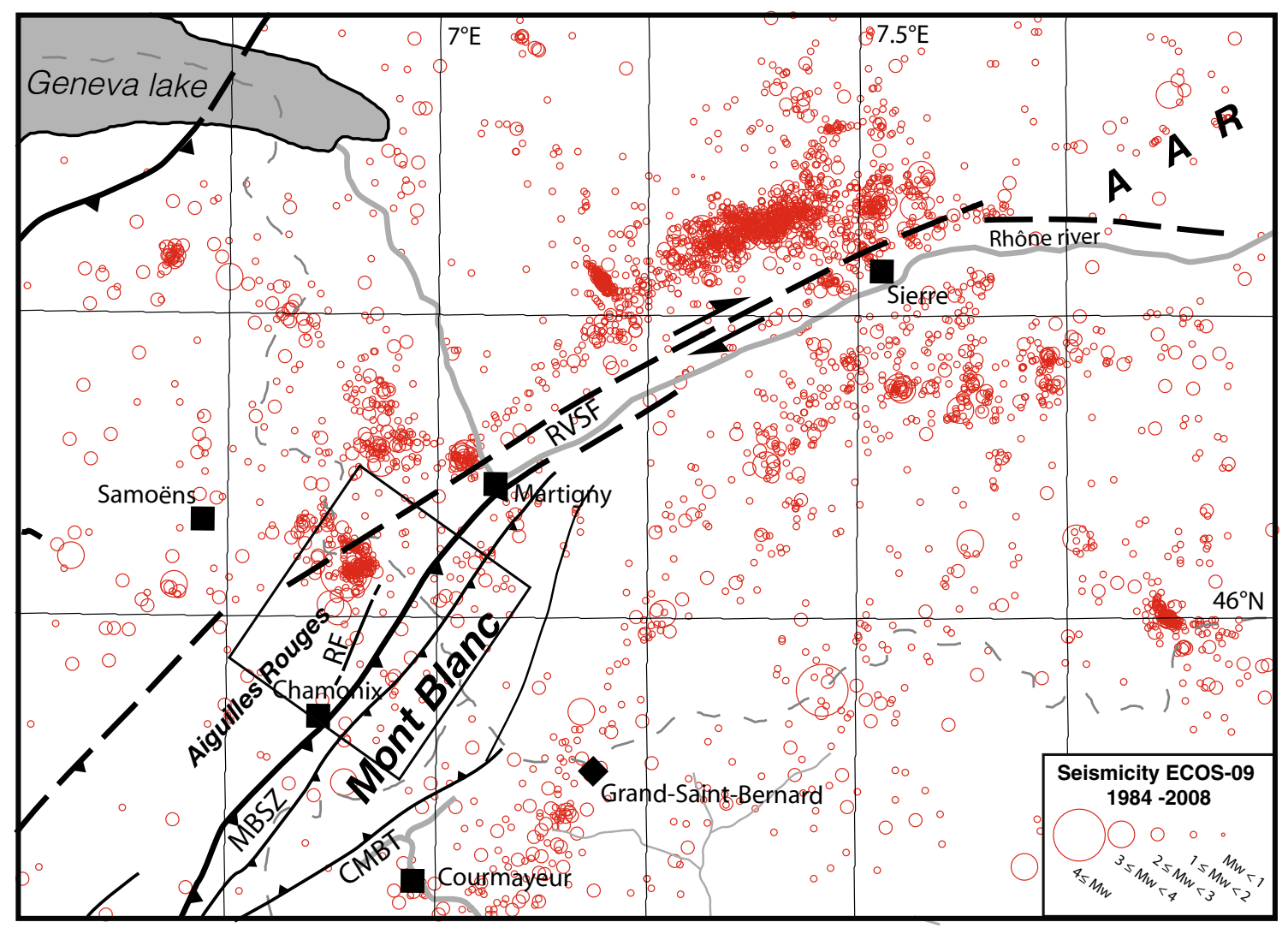

Fig. 2 Instrumental seismicity map for the period 1984-2008 from the ECOS-09 catalogue (Fäh et al. 2011). Black rectangle outlines Fig. 3. Faults labelled as in Fig. 1

Another tectonic regime could possibly be superimposed on this transpressive regime, namely normal faulting associated with erosion during the Alpine glaciation (Glotzbach et al. 2008; Vernant et al. 2013). The analysis of a large series of earthquake focal mechanisms in the western Alps shows an extensive stress regime within the inner Alps but not in the external domain where strike-slip events are dominant (Sue et al. 1999) while in a more detailed stress inversion, Delacou et al.(2004) found a NW-SE-directed extensional regime in the Chamonix area. Note that in a NW-SE compressive regime, local NW-SE extension along NE-SW striking normal faults is not incompatible when considering vertical crustal wedge extrusion (Brunel et al. 1994; Burchfiel et al. 1992).

In the present paper, we shed some light to the question of active tectonics in the Mont Blanc and Aiguilles Rouges massifs by further investigating details of the characteristics of the 1905 Chamonix earthquakes. Macroseismic, tectonic, and instrumental observations are confronted with several hypotheses on the origin of these 1905 earthquakes in Sects. 2, 3 and 4, respectively. Discussion of these observations in Sect. 5 attempts to better document complex active tectonics of the region.

\section{Macroseismic data}

Maximum macroseismic effects of the April 29, 1905 Chamonix earthquake are observed in an area encompassing both the Mont Blanc and Aiguilles Rouges massifs (Fig. 3). The location of the macroseismic epicentre according to SisFrance (2016) is labelled E1 in Fig. 3; the location after Guidoboni et al. (2007) is about $10 \mathrm{~km}$ toward the SE (E1-bis in Fig. 3). Epicentral macroseismic intensity $\mathrm{I}_{0}$ is between VII and VIII according to SisFrance (2016) on the MSK-64 scale (Sponheuer and Karnik 1964). A second large earthquake occurred in the vicinity on August 13, 1905 (E2 in Fig. 3). The magnitudes of both events determined from macroseismic data by Karnik (1969) are very similar $(M=5.7$ and $M=5.6$, respectively), but they differ more in Rovida et al. (2011) $(\mathrm{M}=5.7$ and $\mathrm{M}=5.1$, respectively). The entire area in Fig. 3 is referred to as the epicentral zone hereafter.

Original data show that the largest macroseismic effects of the April 29 earthquake are observed near Argentière north of Chamonix, (Christensen and Ziemendorff 1909; SisFrance 2016). Macroseismic intensity reaches IX on the Rossi-Forel scale (Rossi (de) 1883). Converted into modern intensity scales, this corresponds to VIII on both the 


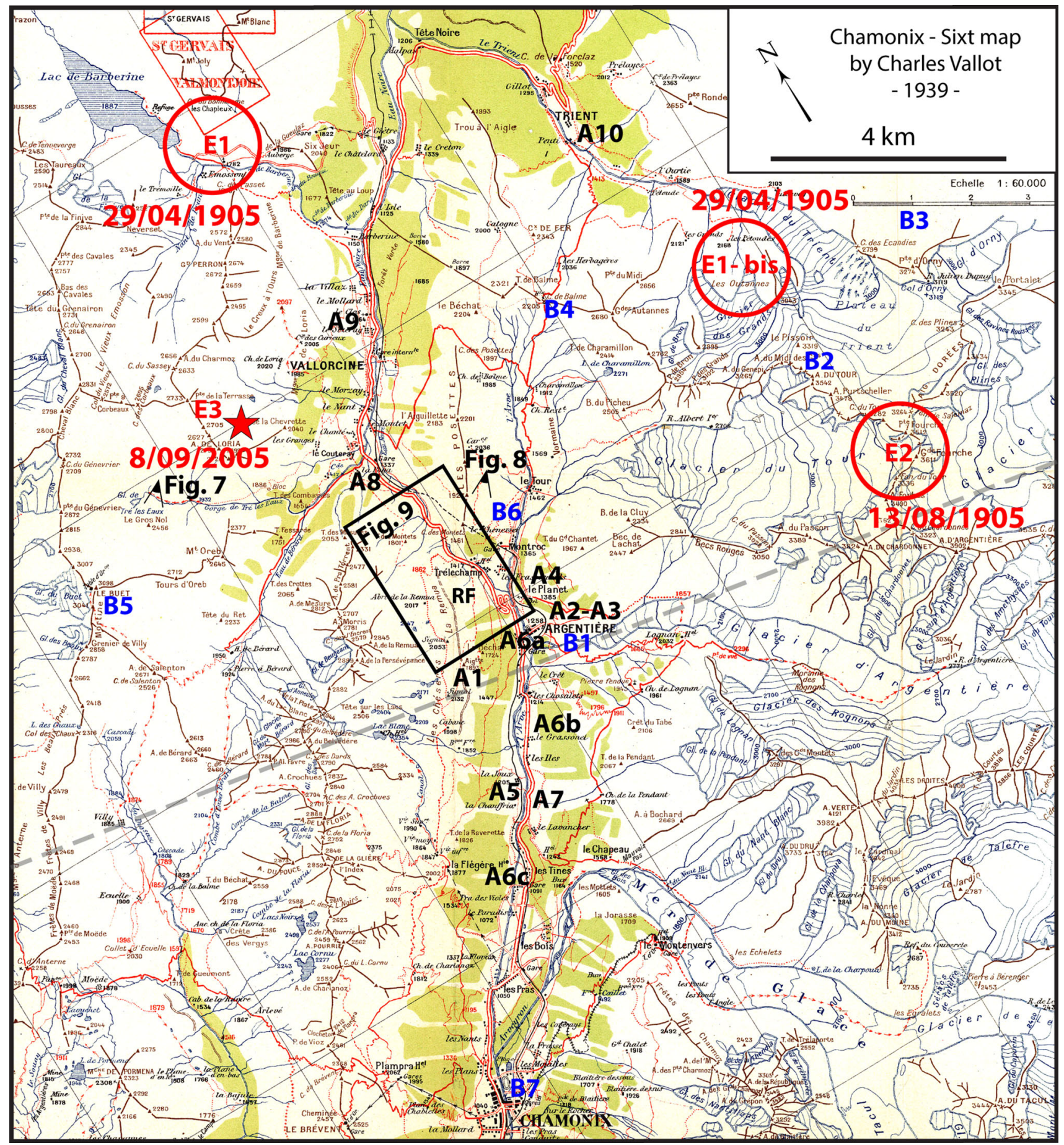

Fig. 3 Locations of the best-documented macroseismic effects of the April 29 (A1-A10 in red) and August 13, 1905 (B1-B7 in blue) events (for details see Table 1). E1 and E2 are the macroseismic epicentres reported by SisFrance (2016) for the April 29 and August 13 events, respectively. E3 shows the epicentre of the Vallorcine,
September 8, 2005 earthquake (Fréchet et al. 2011). RF for the location of the steep Remuaz fault scarp. Background map from the «Chamonix-Sixt»1:60,000 map (Vallot 1939). Grey dotted line is the trace of cross section $\mathrm{A}-\mathrm{A}^{\prime}$ of Fig. 6 (see Fig. 1 for location)

Levret et al. (1988), and V-VI in both the MSK-64 and EMS-98 scales (Alasset 2005), and not to VII as postulated in SisFrance (2016). Furthermore, Guidoboni et al. (2007) locate the macroseismic epicentres of the April 29 (E1-bis)
MSK and EMS-98 scales (e.g. Levret et al. 1988, Cara et al. 2008). The August 13 maximum intensity is VI-VII in the Rossi-Forel scale (Christensen and Ziemendorff 1909). This corresponds to intensity VI MSK-64 according to 
Table 1 Macroseismic effects in the epicentral areas of the April 29, 1905 earthquake: main shock (1-a) and the largest aftershock of August 13, 1905 (1-b)

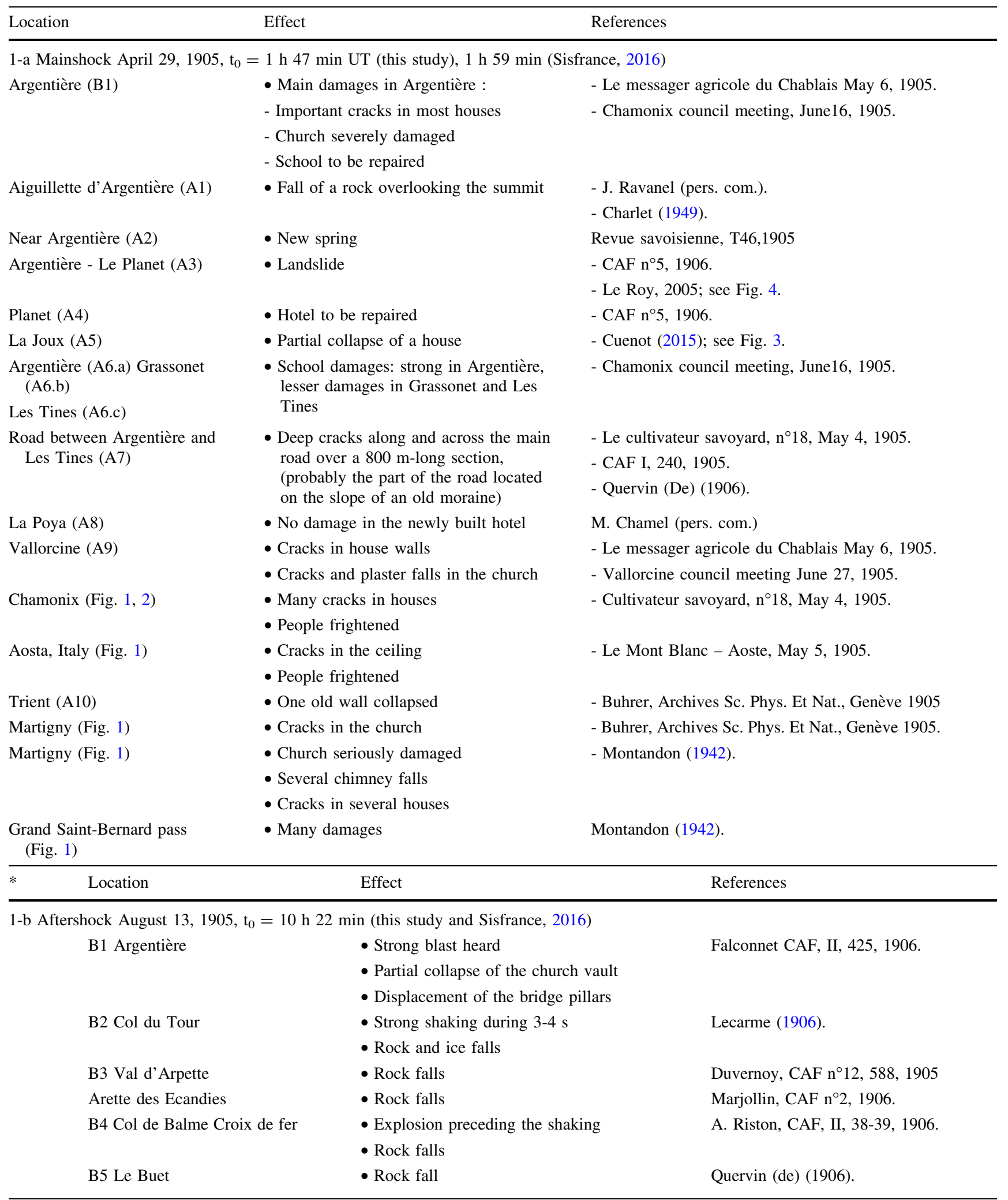


Table 1 continued

\begin{tabular}{lll}
\hline Location & Effect & References \\
\hline B6 Road Argentière-Le Tour & $\bullet$ 2-3 cm cracks along the road & CAF, II, 39, 1906 \\
B7 Chamonix & $\bullet$ Large crack in « Hotel de Genève » & Indicateur de la Savoie, August 19, 1905. \\
& Many cracks in the Railway station & Montandon (1942). \\
Martigny Grand Saint Bernard & $\bullet$ Fall of 2 chimneys &
\end{tabular}

The numbers quoted $\mathrm{An}$ and $\mathrm{Bn}$ refer to the locations reported in Fig. 3. Origin times $\mathrm{t}_{0}$ of these two events are computed by making two hypotheses, Pg or Pn, on the nature of the reported P-wave arrival reported by Szirtes (1909), and rounding the value of $t_{0}$ to the minute (U.T. time). References to documents not cited in the reference list (CAF for Club Alpin Français journal, regional newspapers, archives...) are given in the table

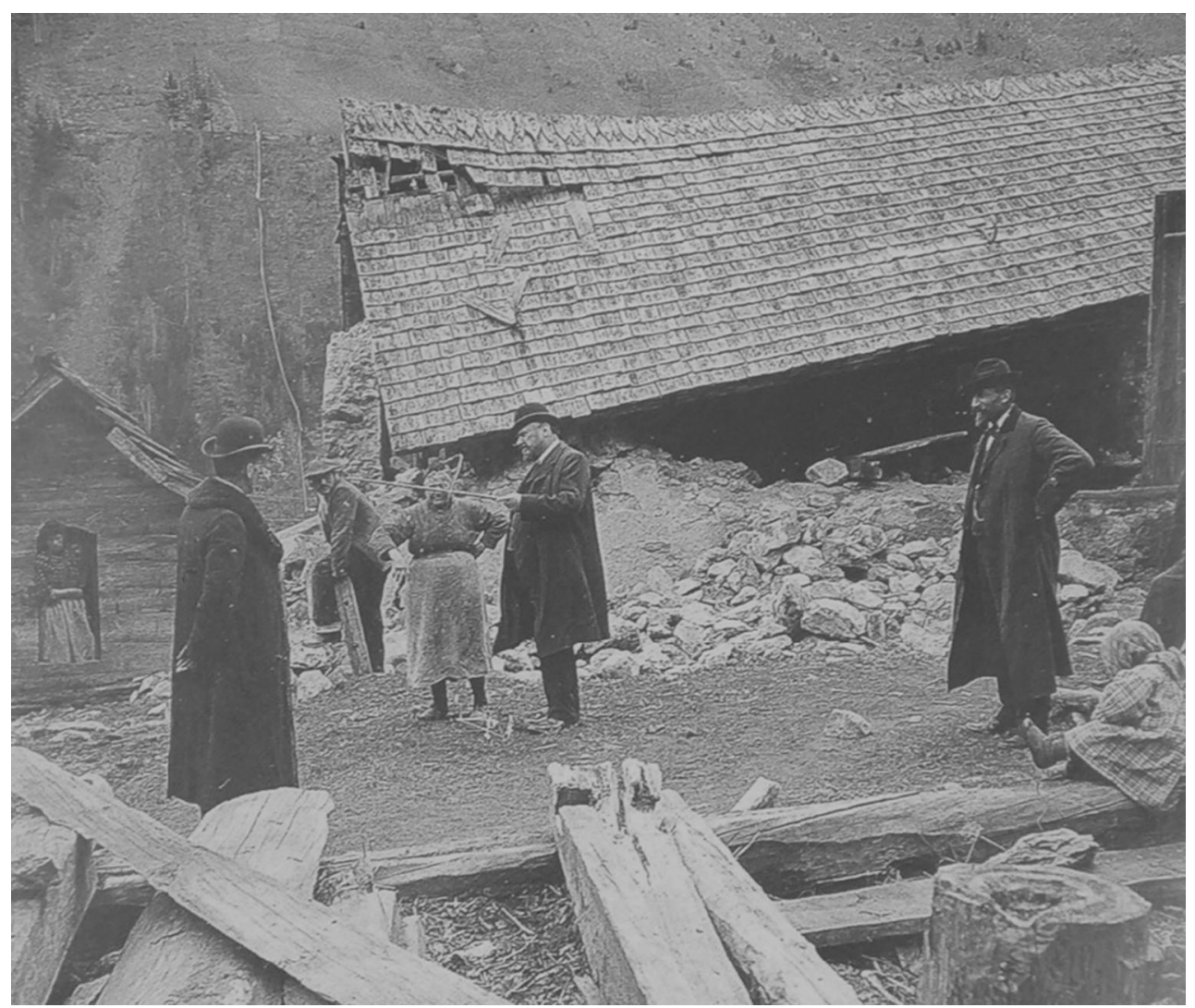

Fig. 4 April 29, 1905 earthquake: partial collapse of a house in La Joux near Argentière (coll. Jules et Michel Payot; Cuenot 2015). For location see A5 in Fig. 3

and August 13 events at very similar locations, $4 \mathrm{~km}$ north of the August 13 SisFrance (2016) macroseismic epicentre (E2, Fig. 3). It is thus very likely that the August 13 earthquake is an aftershock, which occurred in proximity of the fault responsible for the April 29 main shock, somewhere on the upper part of the map shown in Fig. 3. In addition to the August 13 large aftershock, a series of at least ten small earthquakes are reported near Chamonix in SisFrance (2016), all likely to be aftershocks of the April 29, 1905 earthquake.
In order to answer the question of whether or not the same fault system is responsible for both the 1905 earthquakes (E1 or E1-bis and E2 in Fig. 3) and the 2005 Vallorcine earthquake (E3 in Fig. 3), we looked at instrumental data for the 1905 events. These data are not accurate enough for locating the 1905 epicentres with precision. Indeed, among the 27 stations providing arrival time data for the April 1905 main shock, Szirtes (1909) reports 14 P-arrival times at distances between $134 \mathrm{~km}$ (Torino, Italy) and $874 \mathrm{~km}$ (Hamburg, Germany), but incoherency of 
several tenths of seconds among the reported first-arrival times makes locating the 1905 epicentres with sufficient accuracy hopeless. Detailed inspection of macroseismic observations is likely to provide us better information. For this reason, we re-examine and complement the macroseismic observations reported by Rothé (1941) and SisFrance (2016) hereafter. Because the August 131905 event (E2 in Fig. 3) occurred in summer, descriptions associated to its effects are much more numerous throughout the epicentral zone; we thus first describe the effects of the August 131905 event and then those of the April 291905 event (E1 or E1bis in Fig. 3), which occurred at night, just after heavy rain and snow falls.

The August 131905 earthquake occurred in the morning, when several persons were hiking in the Mont Blanc and Aiguilles Rouges massifs. On August 13, 1905, Lecarme (1906) made geodetic observations above the Col du Tour at $3280 \mathrm{~m} \mathrm{NE}$ of Argentière (at location B2 in Fig. 3). He observed many rock-, ice- and snowfalls near the Glacier du Tour west and south of B2 (Fig. 3). He furthermore reports an explosion-like noise heard in the proximity of Argentière. Among different rock-falls, which broadly affected the Mont Blanc and Aiguilles Rouges massifs, Lecarme (1906) concluded that the strongest effects of this earthquake are observed in the area around the Glacier du Tour where SisFrance (2016) located the epicentre (E2 in Fig. 3). Figure 3 also shows the places where the most significant effects were reported, and a brief summary of the effects is given in Table 1. Except for low frequency sounds preceding a strong ground shaking and rock-falls reported from the summit of Le Buet, $3096 \mathrm{~m}$ (Quervin (de) 1906), $3 \mathrm{~km} \mathrm{~W}$ of the 2005 Vallorcine epicentre E3 (B5 in Fig. 3), we found no other report from this NW sector of the study area (Table 1). The area near and around Argentière located within the upper Chamonix valley, is clearly where the reported effects are the strongest. The explosion heard in the immediate vicinity of Argentière (Table 1) further argues in favour of a very close location of the 1905 epicentre. In 2005 , similar strong explosion-like noises were reported in the Vallorcine valley, in proximity of the epicentre E3 shown in Fig. 3, while in the Chamonix valley further south most people reported a rumbling noise at that time (Cara et al. 2007).

In connection with the April 291905 main shock, damages to constructions are widely reported. The most serious damages occurred in Argentière (A6a in Fig. 3; Table 1) and in its vicinity in Grassonet (A6b), La Joux (A5 and Fig. 4), and Les Tines (A6c). In Argentière most houses were heavily damaged with wide cracks in masonry walls. An unpublished note from an inhabitant reports that reinforcements with iron rods were necessary in many houses. These damages of grade 3-4 in many buildings of vulnerability class A are typical of intensity VII in the
EMS-98 scale (Grünthal et al. 1998). To a lesser degree, cracks in houses and churches are also mentioned in Chamonix, Vallorcine (A9), Trient (A10), Martigny and, farther east in Grand-Saint-Bernard (Montandon 1942). Additional evidence for strong ground motion near Argentière are a landslide (A3 and Fig. 5) leading the railway company to change the course of the line (Le Roy 2008), deep cracks along the road between Argentière and Les Tines (A7), and an important $400 \mathrm{l} / \mathrm{s}$ flow of water gushing at the bottom of the landslide place (A2). The fall of a rock from the top of Aiguillette d'Argentière, just above Argentière (A1), is another observation reported by Charlet (1949) that wrote that this rock was present when his father climbed the top in 1885 for the first time. In Vallorcine, the church only presents "insignificant risk" as noted in the report of the town council of June 27, 1905. Farther to the NW, attempts to collect reports in the Samoëns valley, $10-15 \mathrm{~km}$ WNW of Vallorcine, were unsuccessful. Hence the shaking is likely to have caused only minor damages there, if any.

In summary, the location of the strongest macroseismic effects confirms that the April 29 and August 131905 epicentres are most likely located near Argentière in the upper part of the Chamonix valley as reported by Christensen and Ziemendorff (1909), and not in the Vallorcine valley located farther to the north. The fault system responsible for the two 1905 Chamonix earthquakes is thus likely different from that related to the recent 2005 Vallorcine earthquake.

\section{Potential active faults in the Mont Blanc and Aiguilles Rouges massifs}

Leloup et al. (2005) present a detailed structural sketch of the Mont Blanc and Aiguilles Rouges massifs (Fig. 6) together with a likely chronology of the activity of different fault zones. According to these authors, two fault zones could be presently active: the basal thrust fault dipping beneath the Aiguilles Rouges and Mont Blanc massifs, 5-15 km beneath sea level (Alpine sole thrust in Fig. 6), and a back thrust southeast of the Mont Blanc in the Courmayeur valley, Italy (Courmayeur Mont Blanc thrust, labelled CMBT in Fig. 1). Activity of the steeply SE dipping Mont Blanc shear zone (Fig. 6) may have ended 4 Ma ago (Leloup et al. 2005; Glotzbach et al. 2008) although it may presently accommodate right-lateral shear (Egli and Mancktelow 2013). Not noticed as a possible active fault until the 2005 Vallorcine earthquake (E3 in Fig. 3) is a right-lateral strike slip fault, $\mathrm{N}$ of the Aiguilles Rouges massif, and SW of the Emosson lake, in continuity of the Rhône valley-Salvan fault zone (or Vallorcine-Valais shear zone, RVSF in Fig. 1) responsible for the small 2001 


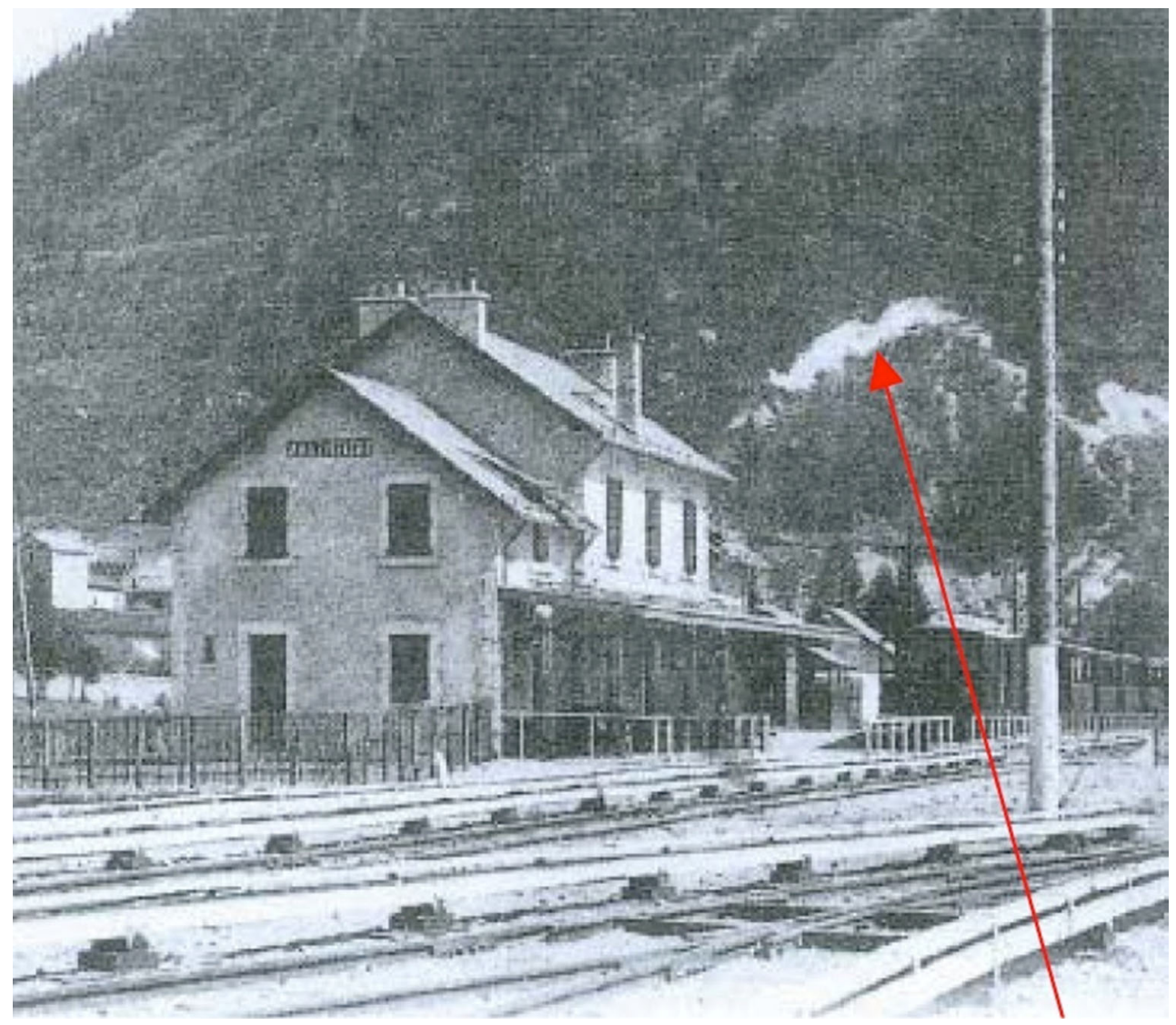

Fig. 5 Argentière/Planet landslide shown by the red arrow, for location see A2-3 in Fig. 3. View looking to the NE from the Argentière railway station, a short time after it was built in 1906. The spring, which appeared after the April 29, 1905 earthquake, was located at the foot of the landslide area (coll. J.P. Gide; Gide and Banaudo 1998)
Fig. 6 Structural section A-A' across the Aiguiles Rouges and Mont Blanc massifs (see location in Fig. 1) (modified from Leloup et al. 2005). Hypocentres of the two 1994 and 2005 earthquakes are projected into the section and into corresponding structures. F1 to F5 indicate the various potential fault zones tested in the text of Sect. 4.3. F1 is a theoretical focal mechanism giving the best fit to the seismic waveforms (see Table 3), F2 corresponds to the Remuaz fault and F3 to the fault activated by the 2005 Vallorcine earthquake

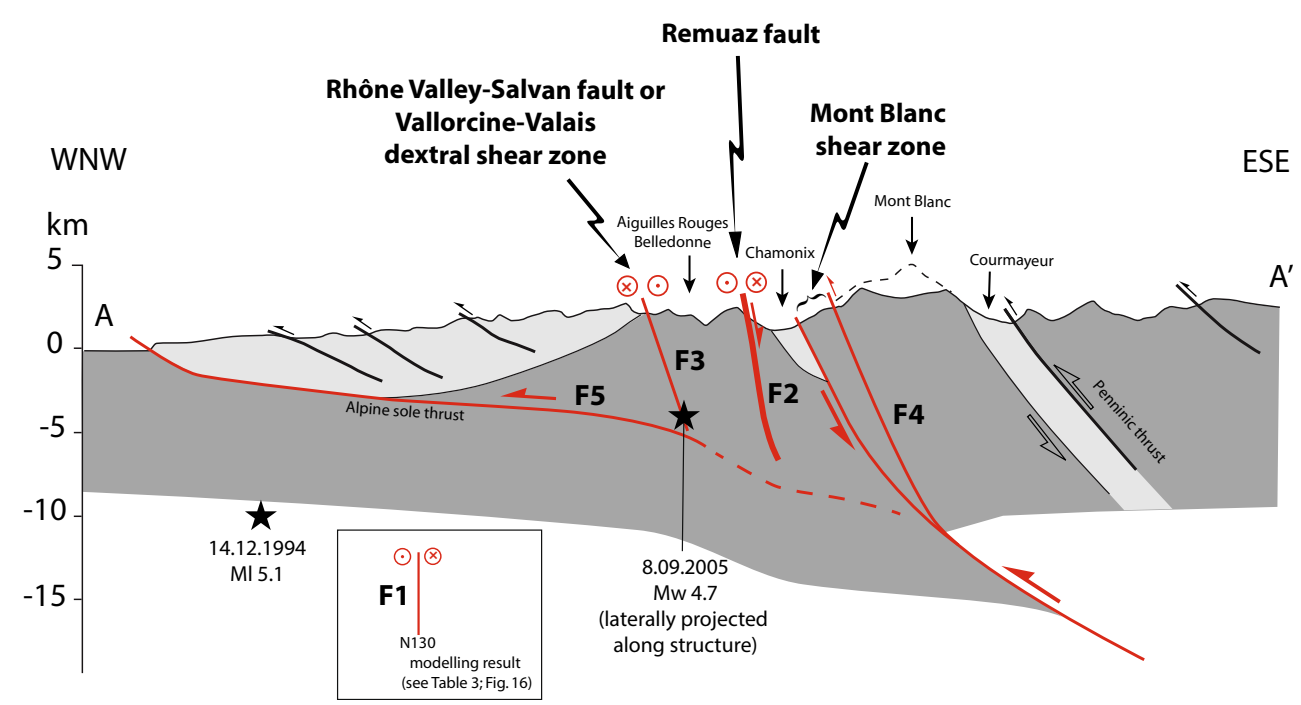


earthquake swarm (Deichmann et al. 2002), and possibly also responsible for the 1915 Martigny earthquake.

\subsection{The Vallorcine fault zone of the Vallorcine-Valais shear zone}

The $\mathrm{M}_{\mathrm{w}}=4.7( \pm 0.2) 2005$ Vallorcine earthquake corresponds to a right-lateral rupture of a fault segment trending $\mathrm{N} 60^{\circ} \mathrm{E}$ at $4 \mathrm{~km}$ depth below sea level (Fréchet et al. 2011; see epicentre F3 in Fig. 6). The rupture probably did not reach the surface during this earthquake but an apparently recent crack is visible in the $350 \mathrm{~m}$-high gneiss block «Gros Nol» (Fig. 7) trending in the same azimuth as the elongated aftershock distribution and in agreement with the focal mechanism of the main shock (Fréchet et al. 2011). This trace of this fault could be the southwestern end of the right-lateral Wildhorn-Martigny fault zone of Delacou et al. (2005) that roughly corresponds to the Rhône ValleySalvan shear zone (Figs. 1, 6). This is a potential active fault segment if one considers the freshness of its trace prior to the 2005 event (Fig. 7).

\subsection{The Remuaz fault}

The Remuaz fault (Fig. 6) corresponds to an ancient geological contact between the Aiguilles Rouges gneiss and the Vallorcine granite (Debelmas 1974, Ayrton et al. 1987), running for about $15 \mathrm{~km}$ between the Rhône and Chamonix valleys. At its southern end (Figs. 1, 2, 8, 9), the geomorphological characteristics of the fault are those of a slightly left-lateral normal fault trending $\mathrm{N} 20$, dipping $70^{\circ}$ to the southeast, with very well marked steeply dipping striations oriented $\mathrm{N} 85^{\circ} \mathrm{E}$ (Fig. 10; Alasset 2005). At a large scale, the Remuaz fault trace follows the structural direction of the Aiguilles Rouges massif and crosses the Col des Montets pass, a former glacial channel connected to the Rhône valley to the northeast. The fault is well marked in the landscape as a 40-60 m-high topographic step near the rim of the upper part of the glacial valley wall (Figs. 8, 9) at an elevation below $2100 \mathrm{~m}$ a.s.l., thus below the highest glacial infill of the last glacial maximum ( $2400 \mathrm{~m}$ a.s.l. at the Last Glacial Maximum, LGM, 20 ka, Kelly et al. 2004; Fig. 9). The Remuaz fault separates two different types of rocks, granite

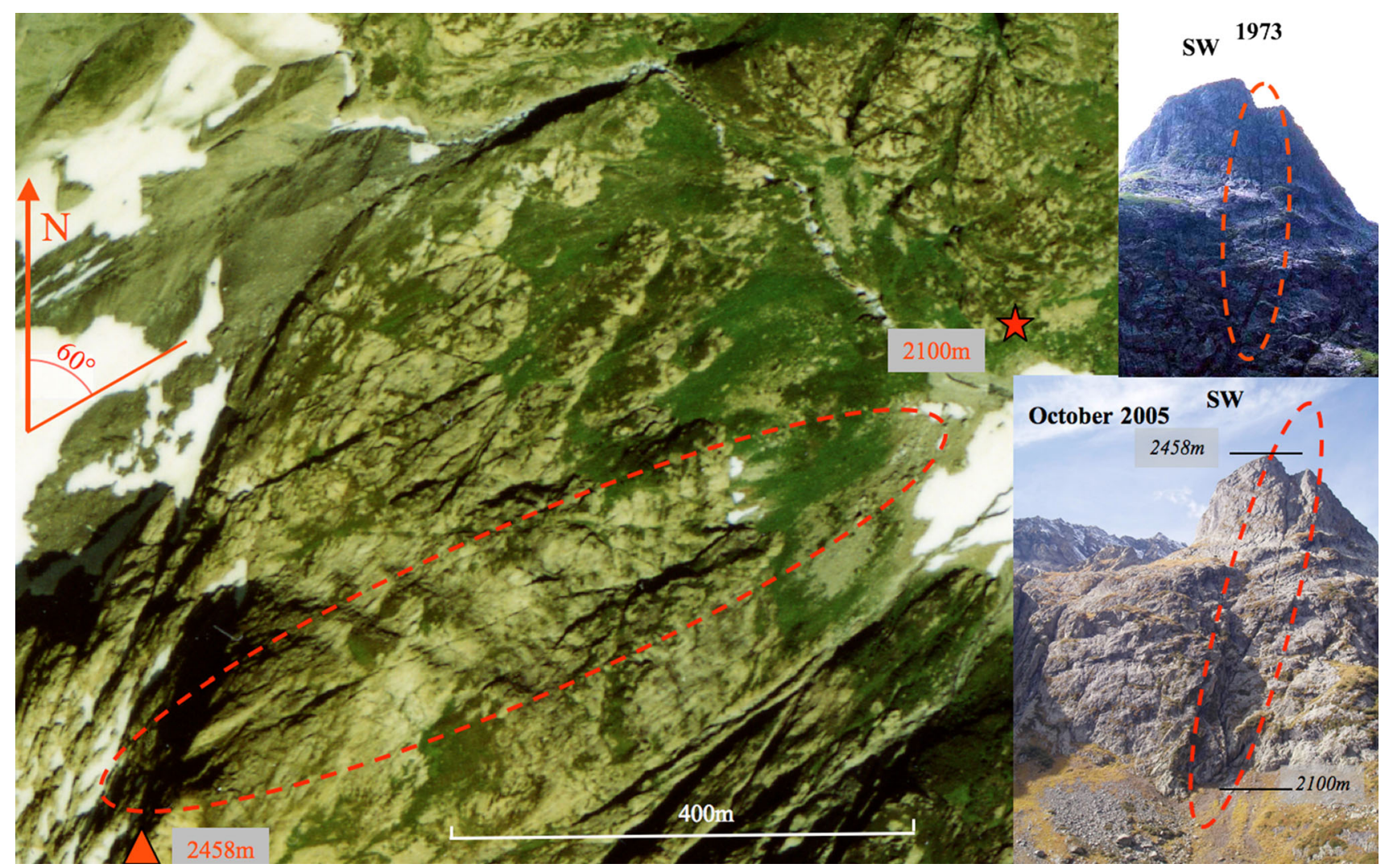

Fig. 7 Aerial view of the narrow $N 60^{\circ}$ trending fault break in the steep northeastern flank of Gros Nol $(2458 \mathrm{~m})$ located at the southwestern end of the Vallorcine-Valais fault zone (tip of the aftershock area of Vallorcine $2005 \mathrm{Mw}=4.7$ earthquake, Frechet et al. 2011). Bedrock break predates the Vallorcine 2005 main shock as evidenced in October 2005 and 1973 photos taken from the point shown by the red star 


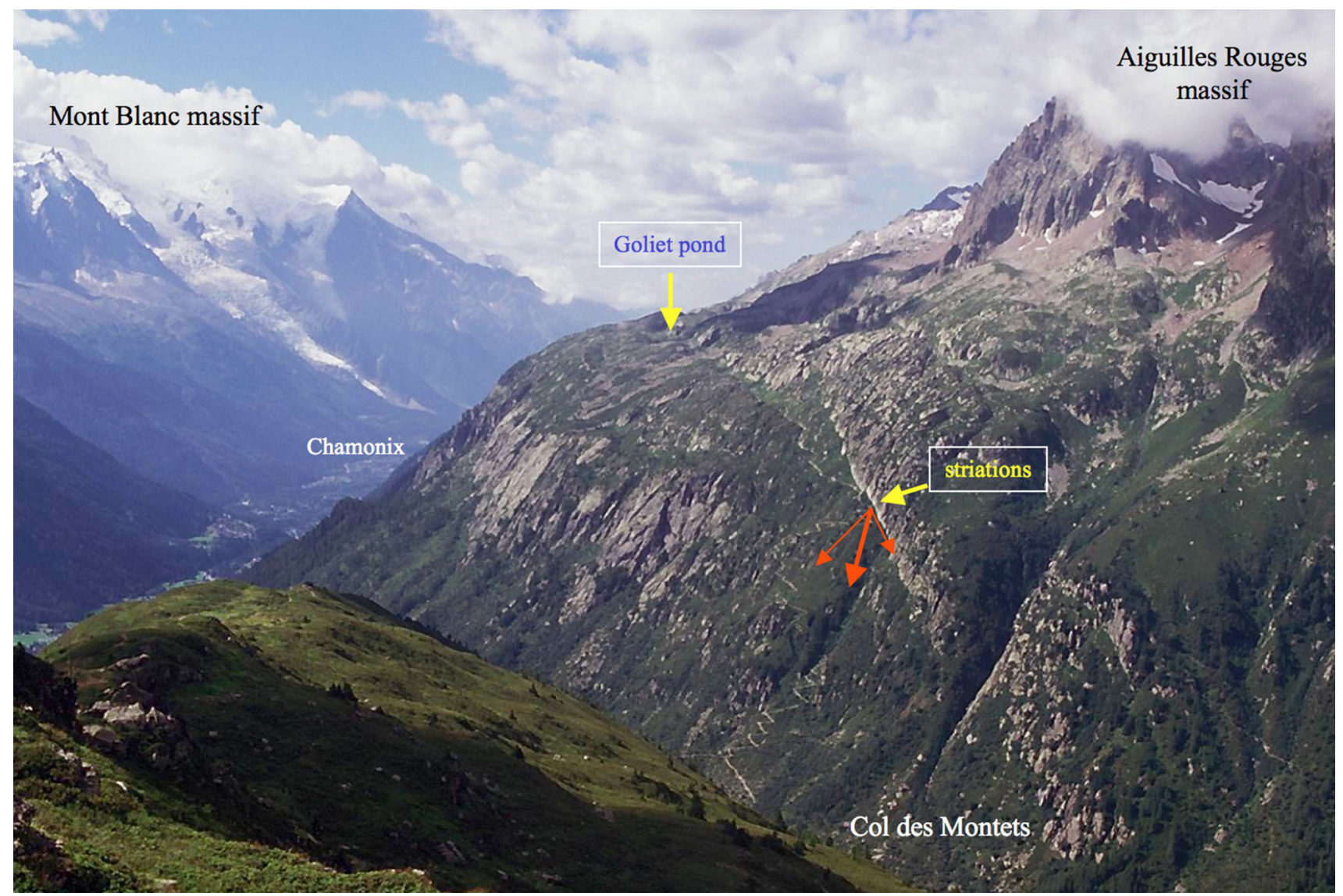

Fig. 8 View of the Remuaz scarp along the eastern edge of the Aiguilles Rouges massif. The scarp is outlined by a clear slope break and topographic step across the massif, and locally by ponding (Goliet pond) and by a freshly striated exhumed basal strip (striations) (Alasset 2005)

in the Aiguilles Rouges in the footwall and gneiss in the hangingwall, thus the topographic step across the fault trace is either a result of differential glacial ablation during the LGM or it is the trace of an active fault, which has been preserved despite several hundreds of meters of ice cover.

The upper part of the several tens of meters high scarp is degraded and convex upward, indicating long lasting erosion. Steeper parts in this upper part show clear sub-horizontal striations indicative of along strike glacial flow, in agreement with glacier channelling towards the Rhône valley as deduced from glacial striations compilations in the massif (Coutterand and Buoncritiani 2006). The basal part of the scarp shows very different aspects, in particular near its northern end above the Col des Montets pass (Figs. 8, 9). There, the base of the scarp is a clean-cut steep wall with traces of steeply dipping striations that become a very clear going downwards the scarp. In addition, while most of the scarp is dark grey coloured and covered by lichens, the lower part of this scarp has been refreshed recently as it shows a light-coloured $20 \mathrm{~cm}$-wide strip for a length of about $40 \mathrm{~m}$, indicating that may have been recently exhumed. This probably freshly exhumed part of the scarp may be due to down-sliding or settling of the colluvial debris wedge in a very steep part of the valley wall, or it may be due to recent normal faulting slip, similar to commonly observed refreshed scarps after large earthquakes along normal fault scarps in Greece or Italy (e.g. Benedetti et al. 2003). In our case, no other recent event except for the 1905 event would be sufficiently large to produce shaking leading to slope destabilization or direct slip on the fault plane. We do not know how long it takes for freshly exposed rocks to regain their dark grey hue and the necessary climatic conditions are for lichens to grow and extend spatially. It thus remains speculative as to whether the observed exhumed basal scarp dates back to faulting or shaking in 1905, or if it is more recent and not of seismic origin.

\subsection{Cosmogenic ${ }^{10} \mathrm{Be}$ surface dating of glacial geomorphology}

To better constrain the age of the geomorphological features near the Remuaz fault plane we carried out cosmogenic ${ }^{10} \mathrm{Be}$ dating of glacially polished bedrock surfaces. While the maximum infill of the LGM glaciers is about $300 \mathrm{~m}$ above our sampling site at $\sim 2050 \mathrm{~m}$ a.s.l., this 

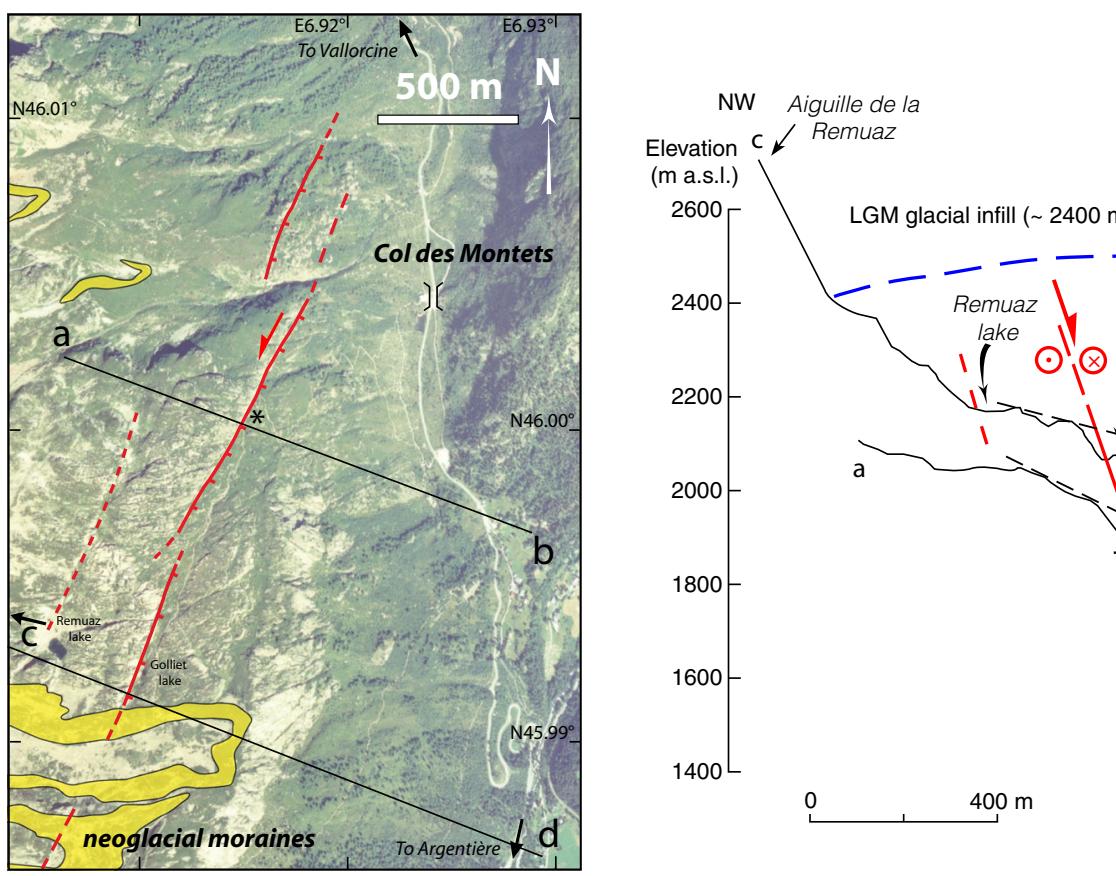

Fig. 9 Left aerial view of northeastern Aiguilles Rouges massif in the vicinity of Col des Montets. In red, trace of Remuaz fault, which tends to disappear under late glacial morain deposits. Right topographic cross sections along the lines ab and cd perpendicular to the mean strike of Remuaz fault. The fault zone was entirely covered by ice during the Last Glacial Maximum. The fault scarp is a

yields a maximum age of $20 \mathrm{ka} \mathrm{BP}$ (Chapron 1999; Jorda et al. 2000) for the glacial morphology. The timing of the different retreat stages (Coutterand and Nicoud 2005) is less well constrained, mostly because the ages were determined in lake deposits near the front of the maximum advances and because the reconstructions of the shape of the glacial volumes rest on few moraine remnants. Clear frontal moranic ridges shown in Fig. 9 straddle the southeastern flank of the Aiguilles Rouges massif but they are likely due to the ending phases of the LGM glacial period and not to the recent Little Ice Age.

We sampled two sets of samples (Table 4). REM1 originates from the steep glacially striated slope of the fault scarp (Fig. 11b), therefore reducing the shielding effect by snow accumulation. REM3, 4 and 5 were sampled near the base of the fault scarp, on glacially striated rocks ("roche moutonnée"), usually covered by snow during the winter season (Fig. 11a).

As expected, Rem 1 has a larger ${ }^{10} \mathrm{Be}$ concentration than the other samples, thus it is likely slightly older than the three others, and we interpret this age of $15 \mathrm{ka}$ as the time when glaciers flowing from the Aiguilles Rouges massif stopped covering this part of the fault scarp. The other samples are younger, 8-11 ka, despite their higher elevation (a few tens of meters), probably because a snow correction is needed (Schildgen et al. 2005). Simple calculations based on
40-60 m-high step clearly visible in the landscape. Outcropping striated scarp is only visible to the north in the steepest slope of valley wall (star on the aerial view, section a, b). Inset lower hemisphere stereoplot of strike and dip of striated normal fault plane (in red) together with the rake of the striations (arrow). Strike and dip of steepest local slope is shown in black

present day snow coverages may imply a $25 \%$ correction for the 8-11 ka ages, i.e. 2-3 ka (e.g. Gosse and Phillips 2001; Mériaux et al. 2009). The precision of this correction is highly dependent on the knowledge of past snow or ice coverages at a local level, which are not known.

In summary, the ages obtained indicate an early retreat of the glaciers $(\sim 15 \mathrm{ka})$ right after the LGM as suggested by Coutterand and Nicoud (2005). If the basal 5 meters of the scarp were exhumed seismically after glacial retreat as suggested by georadar profiles made at the bottom of the fault (Alasset 2005), then this timing provides an upper bound of tectonic movement and a possible average rate of about $0.3 \mathrm{~mm} /$ year. Given the $70^{\circ}$ dip of the fault and the assumed simplified structural geometry of Fig. 6 suggesting upward extrusion of an Aiguilles Rouges crustal wedge, this rate may correspond to less than $1 \mathrm{~mm} / \mathrm{yr}$ perpendicular shortening on the basal thrust and locally surface extension at the location of the Remuaz fault (Fig. 6).

\section{Instrumental data and waveform modelling}

\subsection{Seismic waveform records}

Among the different seismic stations running in 1905, very few were equipped with well-calibrated, damped 


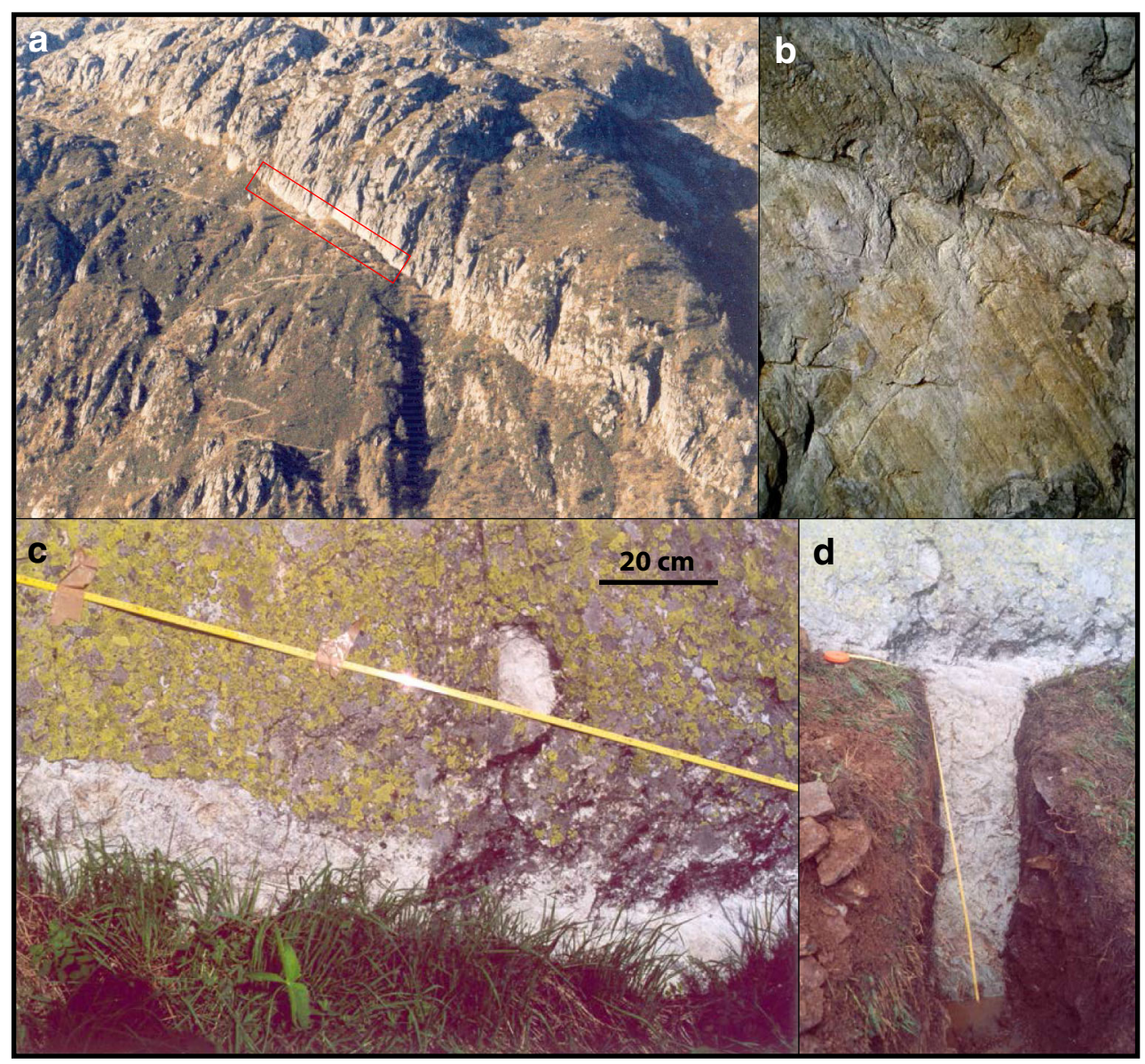

Fig. 10 a Striations observed locally at the base of the Remuaz fault scarp (red rectangle). b Steep striations (pitch of $60^{\circ}$ ) that are clearly not glacial in origin. c Along a length of $40 \mathrm{~m}$ the $20 \mathrm{~cm}$ base of the scarp looks rejuvenated and devoid of lichens. d Continuity of striations within a $1.5 \mathrm{~m}$-deep pit at the foot of the Remuaz fault scarp

$\mathrm{M}_{\mathrm{s}}=\log _{10}(\mathrm{~A} / \mathrm{T})+1.66 \log _{10}(\mathrm{D})+3.3$,

where $\mathrm{A}$ is the maximum amplitude of the ground motion at period $\mathrm{T}$, and $\mathrm{D}$ is the epicentral distance in degree. Depending on the station and component considered, $\mathrm{M}_{\mathrm{s}}$ covers the range $[4.9,5.5]$ with an averaged value $\mathrm{M}_{\mathrm{s}}=5.1$.

In Göttingen, where the August 13 event is well recorded (Fig. 14), the ratio between maximum amplitudes of the April 29 and August 13 events taken from the East component where the signal is the largest yields a difference of $M_{s}$ close to unity. The surface-wave magnitude of the August 13 aftershock can thus be set between 3.9 and 4.5, depending on the magnitude of the April 29 event. It is thus much smaller than those reported in the literature so far (Karnik 1969; Rovida et al. 2011). This difference of magnitudes of around 1 reinforces the conclusion drawn in Sect. 2 that the August 13 event is very likely an aftershock of the April 29 event according to the Bath's law (Båth 1965).
Surface-wave magnitudes $\mathrm{M}_{\mathrm{S}}$ of the main shock determined from the records shown in Figs. 12 and 13 are given in Table 2 according to the IASPEI formula (Vaneck et al. 1962):

\subsection{Magnitudes of the April 29 and August 13, 1905 earthquakes}



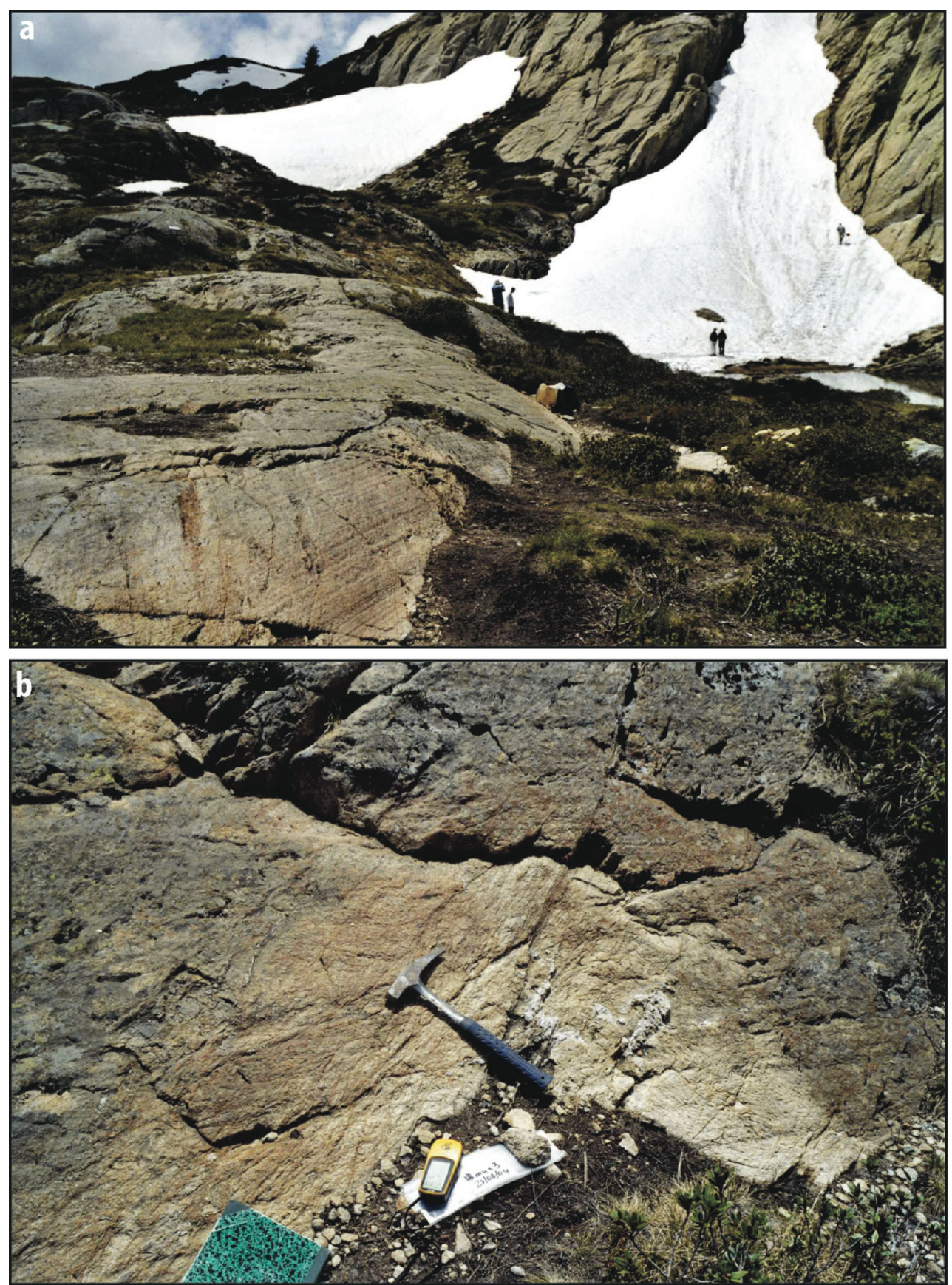

Fig. 11 a Examples of "roche moutonnée" in the hangingwall of the Remuaz fault with clear glacial striations. b Close-up of a quartz-vein sample (to the right of hammer, sample REM3; Table 4) in striated bedrock

\subsection{Waveform modelling}

In order to test how different focal mechanisms are compatible with the recorded waveforms, synthetic seismograms are computed for the Göttingen and Uppsala records. Computations are performed with version 3.30 of the code of Hermann (2013) and a Green's function corresponding to the CRUST2.0 model (Bassin et al. 2000) averaged along the paths between the SisFrance (2016) April 29,
1905 epicentre and the seismic stations. Fitting the raw Wiechert records is not possible with such a 1-D Green's function because of a too simple representation of the elastic structure between the epicentres and the stations. In turn when applying a low-pass filter to both the records and the synthetics, satisfactory fits are obtained. In the application presented here we apply a Butterworth band-pass filter with corner frequencies at 0.02 and $0.07 \mathrm{~Hz}$ with two poles and two zeros. 
Fig. 12 Göttingen horizontal records of the April 29, 1905 earthquake $(\Delta=653 \mathrm{~km})$. Love and Rayleigh waves are dominant on the East and North component, respectively
Fig. 13 Uppsala horizontal records of the April 29, 1905 earthquake $(\Delta=1690 \mathrm{~km})$
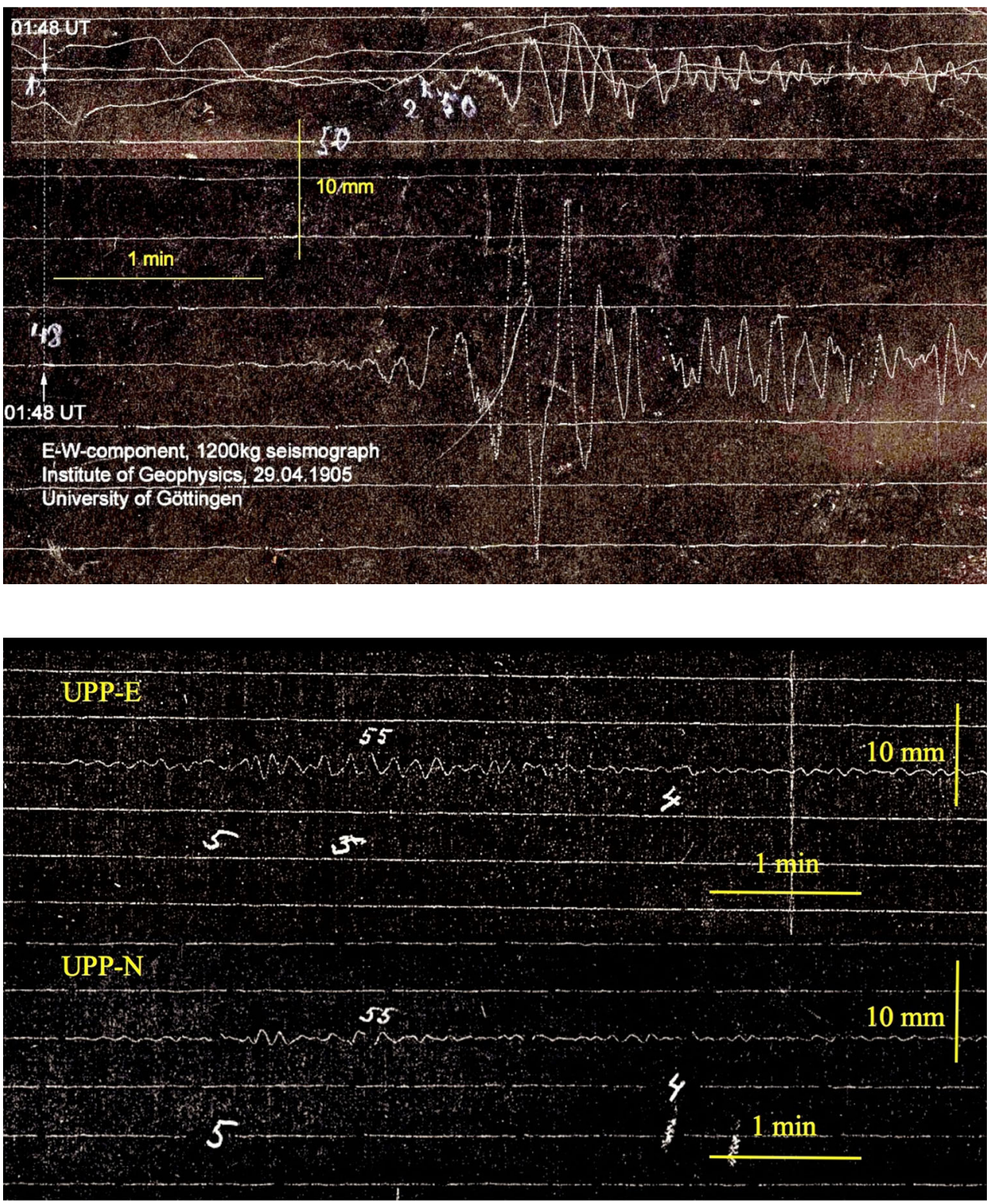

Criteria for testing the quality of the fit are the overall correlation coefficient $r$ and a misfit function $m$ computed over the combined lengths of the records at the two stations.

$$
\begin{aligned}
r & =\frac{\sum_{i, n} w_{n}\left({ }^{n} O_{i}{ }^{n} S_{i}\right)}{\sqrt{\sum_{i, n} w_{n}{ }^{n} O_{i}^{2}} \sqrt{\sum_{i, n} w_{n}{ }^{n} S_{i}^{2}}}, \text { and }, \\
m & =\frac{\sum_{i, n} w_{n}\left|{ }^{n} O_{i}-{ }^{n} S_{i}\right|}{\sum_{i, n} w_{n}{ }^{n} O_{i} \mid}
\end{aligned}
$$

where ${ }^{n} O_{i}$ is the zero-mean observed seismogram at station-component $n$ and time sample $i,{ }^{n} S_{i}$ is the corresponding zero-mean synthetic seismogram, and $w_{n}$ is the weight applied to the data $n$. The misfit function $m$ varies from 1 for a null synthetic signal to zero when the fit is perfect, and it grows as the seismic moment at large magnitudes. Here, the weights $w_{n}$ are set to 1 in Göttingen, and 0.3 (East component) and 0.1 (North component) in Uppsala in order to take into account the signal-to-noise ratio estimated by visual inspection of the seismograms shown in Figs. 12 and 13. Finally, because of the large uncertainty in the origin time of the earthquake and in order to take into account uncertainty in group arrival times, a time-shift correction is applied at each station in order to maximize the correlation coefficient $r$.

Five focal mechanisms F1-F5 and, for each mechanism, three depths $h(5,10$ and $15 \mathrm{~km})$ are tested in the 


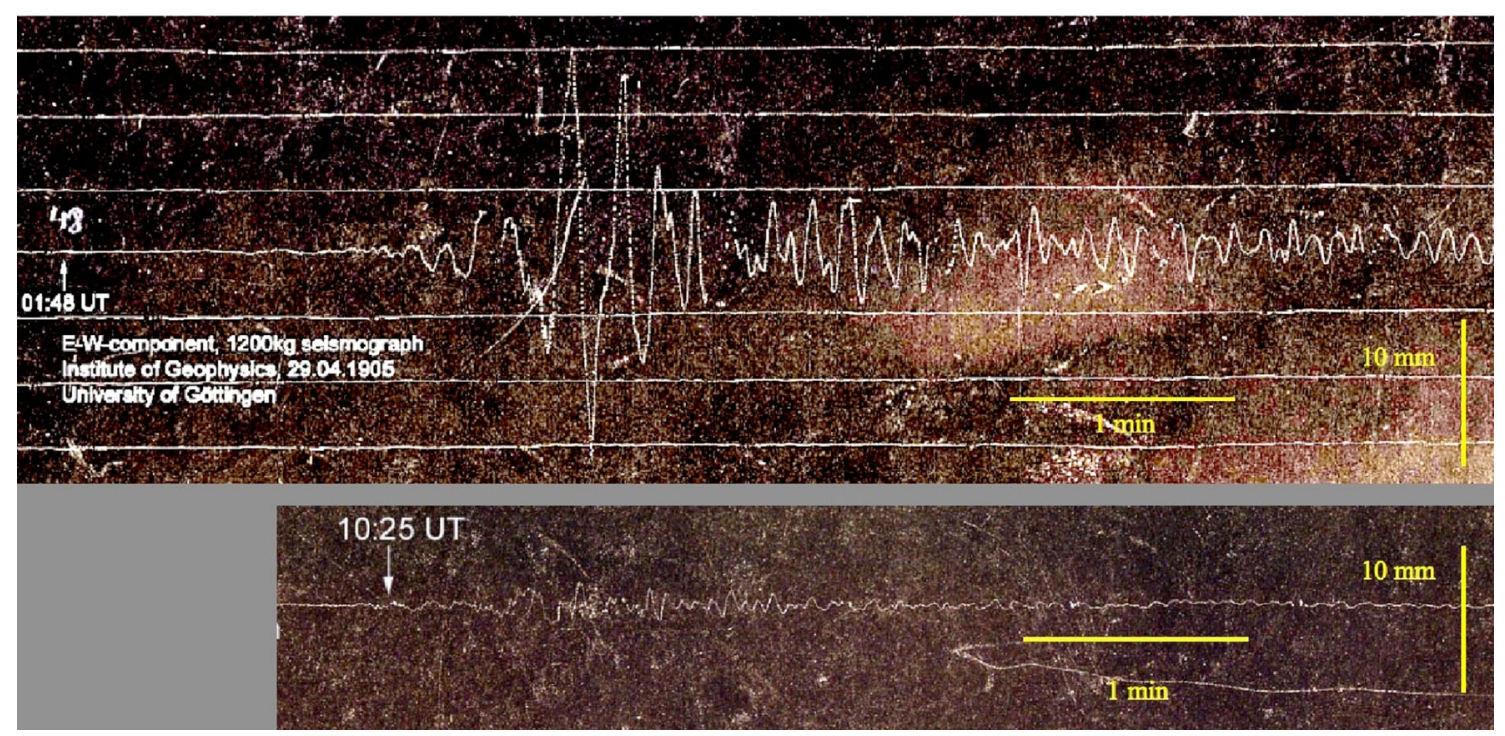

Fig. 14 Records of the April 29 (upper trace) and August 13 (lower trace) drawn at the same scale (Göttingen 1-ton Wiechert instrument, East component)

Table 2 Instrumental parameters and determination of $M_{s}$ at two stations Göttingen (GTT) and Uppsala (UPP) from the E and N components of horizontal Wiechert instruments: $T_{0}$ free period, $\alpha$ damping factor, $V$ magnification, pol. polarization of the instrument, drum speed of the smoke-paper recorder, $\Delta$ epicentral distance, $A z$. back azimuth, $B$ maximum amplitude on the original record, $T$ period at maximum amplitude, $M_{s}$ surface-wave magnitude

\begin{tabular}{|c|c|c|c|c|c|c|c|c|c|c|c|c|}
\hline & Station & Comp. & $\mathrm{T}_{0} \mathrm{~s}$ & $\alpha$ & $\mathrm{V}$ & pol. & $\begin{array}{l}\text { Drum, } \\
\mathrm{mm} / \mathrm{min}\end{array}$ & $\begin{array}{l}\Delta \\
\mathrm{km}\end{array}$ & Az. & $\begin{array}{l}\mathrm{B}, \\
\mathrm{mm}\end{array}$ & $\mathrm{T}$ & $\mathrm{M}_{\mathrm{s}}$ \\
\hline 1 & GTT & $\mathrm{E}$ & 15.3 & 0.46 & 180 & - & 14.9 & 653 & $18^{\circ}$ & 13.5 & 10.0 & 5.5 \\
\hline 2 & GTT & $\mathrm{N}$ & 15.7 & 0.46 & 200 & - & 14.9 & 653 & $18^{\circ}$ & 3.6 & 9.3 & 4.9 \\
\hline 3 & UPP & $\mathrm{E}$ & 9.4 & 0.38 & 187 & + & 14.5 & 1690 & $21^{\circ}$ & 1.1 & 8.5 & 5.1 \\
\hline 4 & UPP & $\mathrm{N}$ & 9.8 & 0.38 & 188 & + & 14.5 & 1690 & $21^{\circ}$ & 0.7 & 7.8 & 4.9 \\
\hline
\end{tabular}

Parameters are from the station book notes and polarities refer to the ground motion. Charlier and Van Gills (1953) report polarities referring to the mass motion, which are opposite to those given in the present table

computations (Table 3; Fig. 16). Focal mechanism F1 is a good overall compromise between maximum correlation $r$ and minimum misfit $m$. Focal mechanism F1 is found without any a priori geological information by applying a coarse grid-search technique in the parameter space (strike $\phi$, $\operatorname{dip} \delta$, rake $\lambda$, and crustal depths $h$ ) with a fixed half duration $\tau / 2=1 \mathrm{~s}$. Focal mechanism F2 corresponds to the strike, dip, and rake of the Remuaz fault as observed in the field (Figs. 9, 10). The F2 synthetic seismograms shown in Fig. 15 fit the records with a better correlation than $\mathrm{F} 1$ for a source at $5 \mathrm{~km}$ depth, although with a slightly smaller correlation and larger misfit for deeper source (Table 3). Focal mechanism F3 corresponds to the right-lateral strike-slip mechanism of the 2005 Vallorcine earthquake (Global CMT 2014). Correlation $r$ is lower than 0.4 and misfit $m$ is larger than unity for this F3 mechanism (Table 3). This is the worst fit among the tested solutions. F4 corresponds to a thrust fault mechanism within the Mont Blanc Shear Zone and F5 is a hypothetical focal mechanism corresponding to the basal thrust beneath the Aiguilles Rouge massif (Fig. 6). Both mechanisms F4 and F5 present rather good correlation coefficients $r$, larger than 0.7 for $h=5 \mathrm{~km}$, but a large misfit $m$ above 0.8 whatever the depth choice. These mechanisms thus cannot be completely excluded but are less likely than F1 and F2. Note that F1 is a pure sinistral strike-slip mechanism not supported by geological observation.

In Table $3, \mathrm{M}_{\mathrm{w}}$ is adjusted in order to independently minimize the misfit at Göttingen and Uppsala, while in Fig. 16 a common value of $\mathrm{M}_{\mathrm{w}}$ is used in the computation for both stations. This figure shows how the misfit function $m$ varies with $\mathrm{M}_{\mathrm{w}}$ for the different focal mechanisms and a fixed depth $h=5 \mathrm{~km}$. It confirms that the smallest misfits are obtained for mechanisms $\mathrm{F} 1 \quad\left(\mathrm{M}_{\mathrm{w}}=5.1\right)$ and $\mathrm{F} 2$ $\left(M_{w}=5.3\right)$. Table 3 and Fig. 16 show that extreme values 
Table 3 Five focal mechanisms Fn (strike $\phi$, dip $\delta$, rake $\lambda$ ), three depths $h$, and half duration $\tau / 2$ are used for computing the seismic waveforms at Göttingen and Uppsala (see also Fig. 6)

\begin{tabular}{|c|c|c|c|c|c|c|c|c|c|c|}
\hline \multirow[b]{2}{*}{ Mec \# } & & \multirow[b]{2}{*}{$r$} & \multirow{2}{*}{$\begin{array}{c}\phi \\
{\left[{ }^{0}\right]}\end{array}$} & \multirow{2}{*}{$\begin{array}{c}\delta \\
{\left[{ }^{\circ}\right]}\end{array}$} & \multirow{2}{*}{$\begin{array}{c}\lambda \\
{\left[^{0}\right]}\end{array}$} & \multirow{2}{*}{$\begin{array}{c}\boldsymbol{h} \\
{[\mathbf{k m}]}\end{array}$} & \multirow{2}{*}{$\begin{array}{l}\tau / 2 \\
{[s]}\end{array}$} & \multicolumn{3}{|c|}{ Mean } \\
\hline & & & & & & & & $\boldsymbol{M}_{W}$ & $m$ & $\sigma_{M_{W}}$ \\
\hline \multirow{3}{*}{ F1 } & 14 & 0.78 & 130 & 90 & 190 & 5 & 1 & 5.1 & 0.67 & 0.1 \\
\hline & 0 & 0.77 & 130 & 90 & 190 & 10 & 1 & 5.1 & 0.70 & 0.2 \\
\hline & 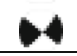 & 0.75 & 130 & 90 & 190 & 15 & 1 & 5.2 & 0.74 & 0.2 \\
\hline \multirow{3}{*}{$\mathbf{F} 2$} & $(\boldsymbol{D})$ & 0.80 & 20 & 70 & 290 & 5 & 1 & 5.3 & 0.67 & 0.2 \\
\hline & $(\omega$ & 0.76 & 20 & 70 & 290 & 10 & 1 & 5.3 & 0.76 & 0.1 \\
\hline & $(1)$ & 0.72 & 20 & 70 & 290 & 15 & 1 & 5.3 & 0.81 & 0.1 \\
\hline \multirow{3}{*}{ F3 } & & 0.37 & 60 & 66 & 169 & 5 & 1 & 5.4 & 1.10 & 0.2 \\
\hline & & 0.32 & 60 & 66 & 169 & 10 & 1 & 5.4 & 1.16 & 0.2 \\
\hline & & 0.25 & 60 & 66 & 169 & 15 & 1 & 5.4 & 1.23 & 0.2 \\
\hline \multirow{3}{*}{ F4 } & & 0.76 & 40 & 70 & 90 & 5 & 1 & 5.5 & 0.82 & 0.1 \\
\hline & & 0.64 & 40 & 70 & 90 & 10 & 1 & 5.5 & 1.06 & 0.1 \\
\hline & & 0.58 & 40 & 70 & 90 & 15 & 1 & 5.5 & 1.12 & 0.1 \\
\hline \multirow{3}{*}{ F5 } & 4 & 0.70 & 40 & 20 & 90 & 5 & 1 & 5.5 & 0.94 & 0.1 \\
\hline & & 0.63 & 40 & 20 & 90 & 10 & 1 & 5.5 & 1.04 & 0.0 \\
\hline & 8 & 0.62 & 40 & 20 & 90 & 15 & 1 & 5.5 & 1.11 & 0.1 \\
\hline
\end{tabular}

The overall correlation coefficient $r$ between the theoretical and the recorded seismograms shows how well both sets of waveforms are fitted. $\mathrm{M}_{\mathrm{w}}$ is the mean of the individual station-component magnitude $\mathrm{M}_{\mathrm{w}}$, and $\sigma_{\mathrm{Mw}}$ is the standard deviation around the mean. See text for details

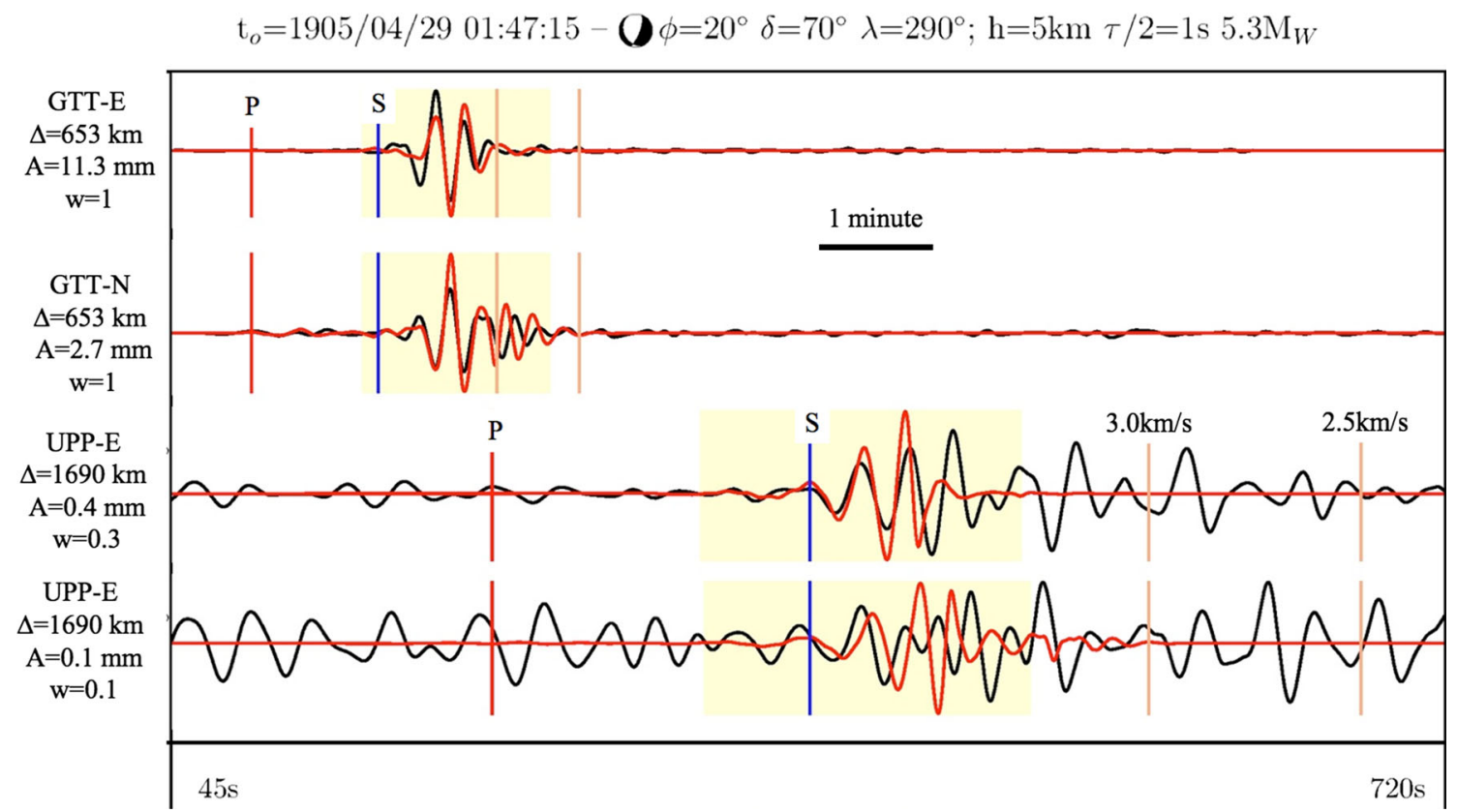

Fig. 15 Fits of the Göttingen (GTT) and Uppsala (UPP) filtered Wiechert records for the focal mechanism of the Remuaz fault and a focal depth of $5 \mathrm{~km}$ (F2 in Table 3). Recorded traces (in black) and computed traces (in red) are normalized. Yellow zones indicate the time intervals where computation of correlation $\mathrm{r}$ and misfit $\mathrm{m}$ are calculated. The $\Delta$ on the left is the epicentral distance, $\mathrm{A}$ is the amplitude of the filtered signals (band-pass between 0.02 and $0.07 \mathrm{~Hz}$ in GTT, 0.02 and $0.05 \mathrm{~Hz}$ in UPP), w is the weight applied to each trace in the computation of $r$ and $\mathrm{m}$. Note that because of the filtering process, amplitudes A are smaller than those of the original records shown in Figs. 12 and 13 


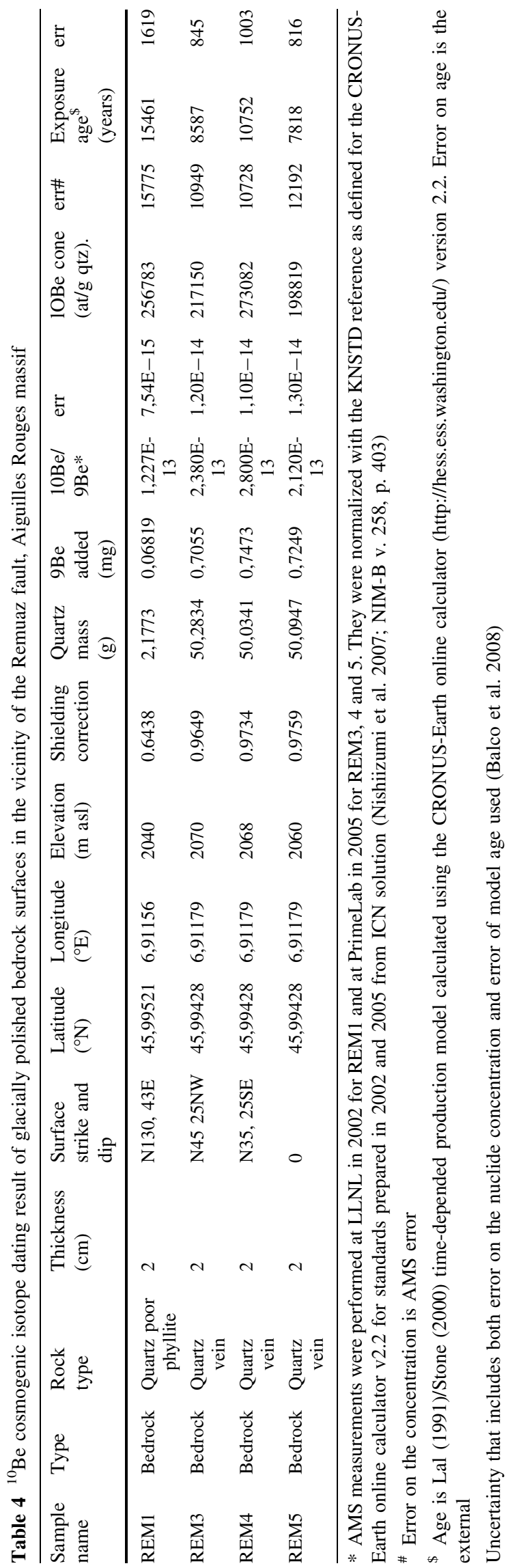

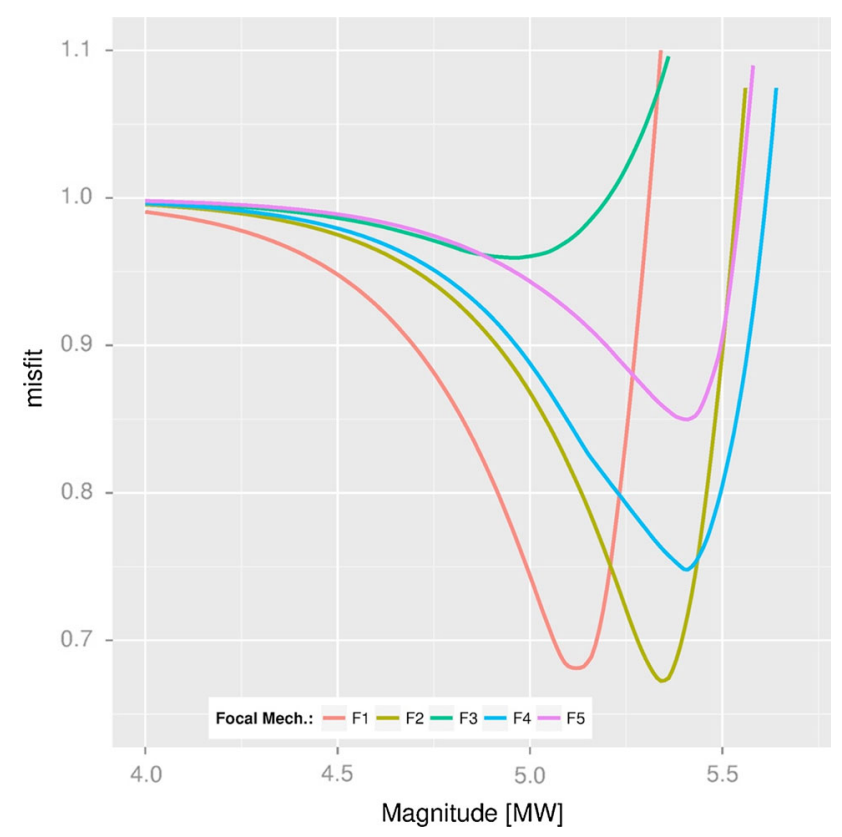

Fig. 16 Variations of the misfit function $m$ versus moment magnitude $M_{w}$ for the five focal mechanisms given in Table 3 and a focal depth of $5 \mathrm{~km}$

of $\mathrm{M}_{\mathrm{w}}$ obtained vary between 5.0 and 5.5 with an averaged value of 5.3 and a preferred value of 5.3 if one selects the focal mechanism corresponding to the Remuaz fault (F2).

In conclusion, this waveform experiment is not very conclusive to discriminate between the possible focal mechanisms. However, it favours the Remuaz fault as the most likely source fault of the 1905 earthquake and it shows that the right lateral fault mechanism of the 2005 Vallorcine earthquake presents the worst fit amongst the observed 1905 seismograms.

\section{Discussion}

Structural geology and tectonic geomorphology show that at least 2 fault systems have clear surface expressions that may result from repeated earthquakes or large surface rupturing events. The $2005 \mathrm{Mw}=4.7$ Vallorcine earthquake, while clearly not a surface rupturing event, nevertheless occurred down-dip from clear surface bedrock cracks with similar kinematics that may indicate a genetic link (Fréchet et al. 2011). While cracks may be preserved for long time in bedrock outcrops, the Gros Nol surface cracks have an apparent freshness that seems to indicate recent movement. From the observations made at present it is not possible to determine the minimum magnitude of earthquake events responsible of these cracks. However, because they are located at the southwestern end of the $\sim 50 \mathrm{~km}$-long fault zone mentioned by Delacou et al. 
(2005), it is not unlikely that a larger magnitude earthquake could also occur there.

The other fault system with a clear surface expression within the epicentral zone of the 1905 Chamonix earthquakes is the Remuaz fault. Its kinematics is clear. It shows up clearly in the landscape as a decametric scarp for several kilometres and has thus to be explained in view of the late glacial occupation of the Chamonix and Vallorcine valleys during the LGM and after (15 ka). What is more ambiguous is whether the exhumation of the lower striated part of the scarp and the more recent white strip at its base are due to seismic activity. Indeed, this part of the fault or scarp is also where the valley slope is the steepest and slope instability above the Col des Montets pass cannot be excluded. If an event of $\mathrm{M}_{\mathrm{w}}=5.3$ is responsible for the $20 \mathrm{~cm}$-high and $40 \mathrm{~m}$-long exhumed base of the scarp then it must have occurred in the first five kilometres of the crust. Another possibility remains, that even without primary surface slip, slope instability may be triggered by shaking due to nearby or deeper earthquakes.

In order to discriminate between the Vallorcine fault zone as part of the Vallorcine-Valais shear zone and the Remuaz fault, macroseismic analysis of original reports coming from the epicentral zone provides arguments to favour the hypothesis that the main shock is not located near the epicentre of the 2005 Vallorcine earthquake and thus that the 2005 and 1905 earthquakes did not occur along the same structure. Although both structures are distant by only $5 \mathrm{~km}$, macroseismic observations would rather place the main shock and its larger aftershock near Argentière in the upper part of the Chamonix valley, NE of the southern termination of the surface trace of the Remuaz fault.

An additional argument may be drawn from the waveform modelling of the Göttingen and Uppsala Wiechert records. Although not very conclusive for the focal mechanisms tested and although sensitivity of the seismogram fits to depth of the focus is very loose, the modelling favours the quasi-normal motion on the Remuaz fault as compared to the right-lateral motion on the Vallorcine fault system. Waveform fit and correlation to the observed seismic waveforms is less good for the thrust motions within the Mont Blanc shear zone and beneath the Aiguilles Rouges but these focal mechanisms cannot be excluded provided the hypocentre is rather shallow (mechanisms F4 and F5 in Table 3. Note that a rather shallow hypocentre is also supported by macroseismic observations. The pattern of macroscopic effects concentrated in a radius of about $5 \mathrm{~km}$ is not compatible with a focus at $15-20 \mathrm{~km}$ depth at the bottom of the seismogenic zone within the plunging lithosphere because it would spread maximum macroseismic effects over a much broader zone. Independently, the explosion-like noise clearly reported after the August 13 aftershock is in favour of a rather surficial hypocentre, similar to that of the 2005 Vallorcine earthquake.

Extension perpendicular to the trend of the Aiguilles Rouges massif such as that associated with the quasi-normal Remuaz fault is compatible with the extensional stress regime along the axial zone of the entire Western Alps, including the Chamonix area, deduced from the analysis of focal mechanisms by Delacou et al. (2004). Such extension is attributed either to gravitational flow following the end of tectonic shortening, and possibly as a consequence of anti-clockwise rotation of Apulia (Delacou et al. 2004; Fréchet et al. 1996, 2011; Thouvenot et al. 2003; Champagnac et al. 2006), or to vertical tectonic movement due to slab break-off (Baran et al. 2014) leading to high rates of exhumation coupled with extension (Fox et al. 2016), or to global climatic change (Champagnac et al. 2009). However, parts of the extension-like deformation southeast of the Aiguilles Rouges massif could also be related to the upward extrusion of an Aiguilles Rouges crustal wedge in a shortening context (e.g. Leloup et al. 2005; Masson et al. 2002; Malavieille 2010) as suggested from the simplified structural cross section (Fig. 6). Finally, even in the absence of far-field plate movement, extension or convergence, high geodetic uplift in the center of the range, hence local extension along Quaternary faults, could be explained by localized post-glacial rebound combined with a low viscosity in the lower crust (Chery et al. 2016). Possibly, tectonic stresses acting in a region of slow strain rates together with post glacial isostatic adjustments to rapidly eroding mountain ranges, could explain why such different fault systems as the Vallorcine and Remuaz faults may be active over only a few kilometres distance.

\section{Conclusion}

This combined study sheds new light on a moderate size earthquake of the Alps. It contributes towards locating it at close proximity of Agentière in the upper part of the Chamonix valley and to firmly determine the second shock of August 131905 as an aftershock of the April 291905 as the main shock. Waveform modelling of seismograms recorded in Göttingen and Uppsala yields a magnitude $\mathrm{Mw}=5.3( \pm 0.3)$ for the April 29 main shock, while inspection of the records of the August 13 event in Göttingen argues in favour of a magnitude about one unit smaller.

Source depth and focal mechanism of the April 29 main shock remain poorly determined from instrumental data. Among the tested mechanisms, forward modelling of the few waveforms available, based on a priori fault models, 
favours a N20 striking quasi normal fault corresponding to the strike of the Remuaz fault, and a poorly determined depth of $5 \mathrm{~km}$. However, two thrust mechanisms, a shallow angle thrust beneath the Aiguilles Rouges massif and a thrust fault within the broad Mont Blanc Shear Zone cannot be excluded. In turn, an event with a dextral strike-slip focal mechanism similar to the 2005 Vallorcine earthquake can probably be excluded.

While the geomorphological expression and kinematic indicators of the Remuaz fault scarp could correspond to the surface trace of the fault that broke in 1905, the N20 alongstrike observations located along the steepest valley walls may also be related to slope instability. Surface exposure dating in the hangingwall at the base of the decametric scarp indicates glacial retreat after $15 \mathrm{ka}$ and concurs for postglacial normal faulting. Whether our observations correspond to present-day seismotectonic activity or to a gravitational cause remains to be determined in the future.

Acknowledgements We thank M. Meghraoui, J. Fréchet, and S. Coutterand for insightful discussions and data sharing. Daniel Egli, an anonymous referee and Stefan Schmid helped us greatly improve a former version of the manuscript. D. Ancey is thanked for communicating the Gros Nol photo of 1973 by B. Leclerc, and J. Ravanel for communicating a report by an anonymous Argentière inhabitant. MC thanks L. Rivera for advices during the waveform modelling computations, and O. Kulhanec in Uppsala and the former staff of Göttingen observatory for information on instrumental parameters.

\section{References}

Alasset, P.J. (2005). Sismotectonique et identification des sources sismiques en domaine de déformation lente : cas des Pyrénées Occidentales et des Alpes du Nord (France). Le Tsunami créé par le séisme de Zemmouri $(\mathrm{Mw}=6.9$, Algerie $)$ du 21 mai 2003. Ph.D. thesis, University of Strasbourg, 214 pp.

Armijo, R., Deschamps, A., \& Poirier, J. P. (1986). Carte sismotectonique: Europe et Bassin méditerranéen. Paris: Institut de physique du globe.

Ayrton, S., Barféty, J. C., Bellière, J., Gubler, Y., \& Jemelin, L. (1987). Carte géologique de Chamonix (1/50000). Orléans: BRGM.

Balco, G., Stone, J. O., Lifton, N. A., \& Dunaï, T. J. (2008). A complete and easily accessible means of calculating surface exposure ages or erosion rates from ${ }^{10} \mathrm{Be}$ and ${ }^{26} \mathrm{Al}$ measurements. Quaternary Geochronology, 3, 174-195.

Baran, R., Friedrich, A. M., \& Schlunegger, F. (2014). The late Miocene to Holocene erosion pattern of the Alpine foreland basin reflects Eurasian slab unloading beneath the western Alps rather than global climate change. Lithosphere, 6(2), 124-131.

Bassin, C., Laske, G., \& Masters, G. (2000). The current limits of resolution for surface wave tomography in North America. EOS Transactions, $A G U, 81, \mathrm{~F} 897$.

Båth, M. (1965). Lateral inhomogeneities in the upper mantle. Tectonophysics, 2, 483-514.

Benedetti, L., Finkel, R., King, G., Armijo, R., Papanastassiou, D., Ryerson, F. J., et al. (2003). Motion on the Karapelli fault (Greece) prior to the 1981 earthquake sequence determined from $36 \mathrm{Cl}$ cosmogenic dating. Terra Nova, 15, 118-124.
Bernardi, F., Braunmiller, J., \& Giardini, D. (2005). Seismic moment from regional surface-wave amplitudes: Applications to digital and analog seismograms. Bulletin of the Seismological Society of America, 95, 408-418.

Brunel, M., Arnaud, N., Tapponnier, P., Pan, Y., \& Wang, Y. (1994). Kongur Shan normal fault: Type example of mountain building assisted by extension (Karakoram fault, eastern Pamir). Geology, 22, 707-710.

Burchfiel, B. C., Chen, Z., Kip, V. H., Liu, Y., Leigh, H. R., Deng, C., et al. (1992). The South Tibetan Detachment system, Himalayan Orogen: Extension contemporaneous with and parallel to shortening in a collisional mountain belt. Geol Soc Am Special Paper, 269, 1-46.

Cara, M., Alasset, P.J., Sira, C. (2008). Magnitude of historical earthquakes, from macroseismic data to seismic waveform modelling: application to the Pyrenees and a 1905 earthquake in the Alps. In J. Fréchet, M. Meghraoui \& M. Stucchi (Eds.). Historical Seismology Interdisciplinary Studies of Past and Recent Earthquakes Serie, Modern Approaches in Solid Earth Sciences, 2, (pp. 363-378). Springer.

Cara, M., Schlupp, A., Sira, C. (2007). Observations sismologiques: sismicité de la France en 2003, 2004, 2005 (199 pp.). Bureau Central Sismologique Français, ULP/EOST-CNRS/INSU, Strasbourg.

Champagnac, J. D., Schunegger, F., Norton, K., Von Blanckenburg, F., Abbühl, L. M., \& Schwab, M. (2009). Erosion-driven uplift of the modern Central Alps. Tectonophysics, 474, 236-249. doi:10.1016/j.tecto.2009.02.024.

Champagnac, J.-D., Sue, C., Delacou, B., Tricart, P., Allanic, C., Burkhard, M. (2006). Miocene lateral extrusion in the inner western Alps revealed by dynamic fault analysis. Tectonics 25/3. Doi: $10.1029 / 2004$ tc001779.

Chapron E. (1999). Contrôles climatiques et sismo-tectoniques de la sedimentation lacustre dans l'avant-pays alpin (lac du Bourget) durant le Quaternaire recent. Géologie Alpine, Mémoire H.S., 30, p. 261.

Charlet, A. (1949). Vocation alpine (206 pp.). Editions Victor Attinger, Neuchatel, Paris.

Charlier, C. \& Van Gils, J.M. (1953). Liste des stations sismologiques mondiales (282 pp.). Observatoire Royal de Belgique, Uccle.

Chery, J., Genti, M., \& Vernant, P. (2016). Ice cap melting and lowviscosity crustal root explain the narrow geodetic uplift of the Western Alps. Geophys Res Lett, 43, 3193-3200.

Christensen A, Ziemendorff G (1909). Les tremblements de terre ressentis pendant l'année 1905 (543pp.). Bureau Central de 1'Association Internationale de Sismologie, série B. Catalogue partie I, Strasbourg.

Coutterand, S., \& Buoncritiani, J. F. (2006). Paléogéographie du dernier maximum glaciaire du pléistocène récent de la région du massif du Mont Blanc, France. Quaternaire, 17, 35-43.

Coutterand, S., \& Nicoud, G. (2005). Les stades de retrait du glacier de l'Arve entre le verrou de Cluses et l'ombilic de Chamonix au cours du Tardiglaciaire (Vallée de l'Arve, Haute-Savoie). Quaternaire, 16, 85-94.

Cuenot, S. (2015). Le roman de Chamonix (401 pp.). Editions Guérin, Chamonix.

Debelmas, J. (1974). Géologie de la France, Les Chaînes plissées du cycle Alpin et leur avant-pays Vol II (544 pp.). Editions Doin. Paris.

Deichmann, N., Baer, M., Braunmiller, J., Ballarin Dolphin, D., Bay, F., Bernardi, F., et al. (2002). Earthquakes in Switzerland and surrounding regions during 2001. Eclogae geologicae Helvvetiae, 95, 249-261.

Delacou, B., Deichmann, N., Sue, C., Thouvenot, F., Champagnac, J. D., \& Burkhard, M. (2005). Active strike-slip faulting in the 
Chablais area (NW Alps) from earthquake focal mechanisms and relative locations. Eclogae Geologicae Helvetiae, 98, 189-199.

Delacou, B., Sue, C., Champagnac, J. D., \& Burkhard, M. (2004). Present day geodynamics in the bend of the western and central Alps as constrained by earthquake analysis. Geophysical Journal International, 158, 753-774.

Egli, D., \& Mancktelow, N. (2013). The structural history of the Mont Blanc with regard to models for its recent exhumation. Swiss Journal of Geosciences, 106, 469-489. doi:10.1007/s00015-0130153-5.

Fäh, D., Giardini, D., Kästli, P., Deichmann, N., Gisler, M., SchwarzZanetti, G., Alvarez-Rubio, S., Sellami, S., Edwards, B., Allmann, B., Bethmann, F., Wössner, J., Gassner-Stamm, G., Fritsche, S., Eberhard, D. (2011). ECOS-09 Earthquake Catalogue of Switzerland Release 2011. Report and Database. Public catalogue, 17.4.2011. Swiss Seismological Service ETH Zürich, Report SED/RISK/R/001/20110417.

Fäh, D., Moore, J. R., Burjanek, J., Iosifescu, I., Dalguer, L., Dupray, F., et al. (2012). Coupled seismogenic geohazards in Alpine regions. Bolletino di Geofisica Teoretica e Applicata, 53, 485-508.

Fox, M., Herman, F., Willet, S. D., \& Schmid, S. (2016). The exhumation history of the European Alps inferred from linear inversion of thermometric data. American Journal of Science, $316,505-541$.

Fréchet, J., Thouvenot, F., Frogneux, M., Deichmann, N., \& Cara, M. (2011). The Mw 4.5 Vallorcine (French Alps) earthquake of 8 September 2005 and its complex aftershock sequence. Journal of Seismology, 15, 43-58.

Fréchet, J., Thouvenot, F., Jenatton, L. Hoang-Trong, Pho, \& Frogneux, M. (1996). Le séisme du Grand-Bornand (HauteSavoie) du 14 décembre 1994: un coulissage dextre dans le socle subalpin. Comptes Rendus de l' Académie des Sciences Paris, $323,517-524$

Fritsche, S., \& Fäh, D. (2009). The 1946 magnitude 6.1 in the Valais: site-effects as contributor to the damage. Swiss Journal of Geoscences, 102, 423-439.

Gide, J.P. \& Banaudo, A. (1998). Les trains du Mt Blanc, Vol. 1 (195 pp.). Ed. du Capri.

Global CMT (2014). Global CMT catalog date: 2005/09/08, Chamonix event id: 200509081127A http://goo.gl/PVg3Py (last access November 2014).

Glotzbach, C., Reinecker, J., Daniski, M., Rahn, M., Frisch, W., Spiegel, C. (2008). Neogene exhumation history of the Mont Blanc massif, western Alps. Tectonics, 27, TC4011, doi:10.1029/ 2008TC002257.

Gosse, J. C., \& Phillips, F. M. (2001). Terrestrial in situ cosmogenic nuclides: theory and application. Quaternary Science Reviews, 20, 1475-1560.

Grünthal, G., Musson, R.M.W., Schwarz, J., Stucchi, M. (eds.) (1998). European Macroseismic Scale 1998 EMS-98, Cahiers du Centre Européen de Géodynamique et de Séismologie, 15 (99 pp.), Luxembourg.

Guidoboni, E., Ferrari, G., Mariotti, D., Comastri, A., Tarabusi, G., Valensise, G. (2007). CFTI4Med, Catalogue of Strong Earthquakes in Italy (461 B.C.-1997) and Mediterranean Area (760 B.C.-1500). INGV-SGA. http://storing.ingv.it/cfti4med, accessed May 25, 2016.

Hermann, R. (2013). Computer programs in seismology: an evolving tool for instruction and research. Seismological Research Letters, 84, 1081-1088. doi:10.1785/022011009.

Jorda, M., Rosique, T., \& Evin, J. (2000). Données nouvelles sur l'âge $\mathrm{du}$ dernier maximum glaciaire dans les Alpes méridionales françaises. Comptes Rendus de l' Académie des Sciences Paris, $331,187-193$
Karnik, V. (1969). Seismicity of the European Area, Part 1 (364 pp.). Reidel, Dordrecht.

Kelly, M. A., Buonchristiani, J.-F., \& Schlüchter, C. (2004). A reconstruction of the last glacial maximum (LGM) ice-surface geometry in the western Swiss Alps and contiguous Alpine regions in Italy and France. Eclogae Geologicae Heletiae, 97, 57-75.

Lal, D. (1991). Cosmic ray labeling of erosion surfaces: in situ nuclide production rates and erosion models. Earth and Planetary Science Letters, 104, 424-439.

Le Roy, P.L. (2008). Le Mont-Blanc Express (158 pp.). Ed. Glénat, Grenoble.

Lecarme, J. (1906). Le tremblement de terre du 13 août observé en haute montagne. La montagne, Club Alpin Français, 9, 421-425.

Leloup, P.H., Arnaud, N., Lacassin, R., Sobel, E.R. (2007). Reply to comment by Y. Rolland et al. on "Alpine thermal and structural evolution of the highest external crystalline massif: The Mont Blanc". Tectonics, 26, TC2016, doi:10.1029/2006TC002022.

Leloup, P.H., Arnaud, N., Sobel, E.R., Lacassin, R. (2005). Alpine thermal and structural evolution of the highest external crystalline massif : the Mont Blanc. Tectonics, 24, TC4002, doi:10. 1029/2004TC001676.

Levret, A., Loup, C., Goula, X. (1988). The Provence earthquake of 11 th June 1909 (France). A new assessment of near field effects. In Seismic hazard in Mediterranean regions. In J. Bonnin; M. Cara, A. Cisternas, R. Fantechi (Ed.), Modern Approaches in Geophysics, (pp. 383-399). Kluwer Academic Publishers, Dordrecht.

Malavieille, J. (2010). Impact of erosion, sedimentation and structural heritage on the structure and kinematics of orogenic wedges : analog models and case studies. Geological Society of America, GSA Today, 20/1, doi: 10.1130/GSATG48A.1.

Masson, F., Gal, F., \& Leloup, P. H. (2002). Une carte gravimétrique hature rsolution du massif du Mont-Blanc: implications structurales. Comptes Rendus Geoscience, 334, 1011-1019.

Mériaux, A.-S., Sieh, K., Finkel, R. C., Rubin, C. M., Taylor, M. H., Meltzner, A. J., et al. (2009). Kinematic behavior of southern Alaska constrained by westward decreasing postglacial slip rates on the Denali Fault, Alaska. Journal of Geophysical Research, 114, B03404. doi:10.1029/2007JB005053.

Montandon, F. (1942). Les séismes de forte intensité en Suisse. Revue pour l'étude des calamités, 5, 167-168.

Nishiizumi, K., Imamura, M., Caffee, M. W., Southon, J. R., Finkel, R. C., \& McAninch, J. (2007). Absolute calibration of $10 \mathrm{Be}$ AMS standards. Nuclear Instruments \& Methods in Physics Research, Section B: Beam Interactions with Materials and Atoms, 258, 403-413. doi:10.1016/j.nimb.2007.01.297.

Plan-séisme (2015). Zonage sismique de la France. http://www. planseisme.fr/Zonage-sismique-de-la-France.html, accessed May 25, 2016.

Quervin (de), A. (1906). Die Erdbeben der Schweiz im Jahre 1905. Annalen der schweizerischen meteorologischen Centralanstalt, year, 42, 8.

Rolland, Y., Corsini, M., Rossi, M., Cox, S.F., Pennacchioni, G., Mancktelow, N., Boullier, A.M. (2007). Comment on «Alpine thermal and structural evolution of the highest external crystalline massif: the Mont Blanc » by P.H. Leloup, N. Arnaud, E.R. Sobel, and R. Lacassin. Tectonics, 26, TC2015, doi : 10. 1029/2006TC001956.

Rossi (de), M. S. (1883). Programma dell'osservatorio ed archivio centrale geodinamico. Bullettino del Vulcanismo Italiano, Anno $X$, no, 3-5, 49-128.

Rothé, J.P. (1941). Les séismes des Alpes françaises en 1938 et la séismicité des Alpes occidentales. In E. Rothé (Ed.), Annales de l'Institut de Physique du Globe, T3, 52-53, Strasbourg 
Rovida A, Camassi R, Gasperini P, Stucchi M (2011). CPTI11, the 2011 version of the Parametric Catalogue of Italian Earthquakes. http://emidius.mi.ingv.it/CPTI, accessed June 15, 2016.

Schildgen, T. F., Phillips, W. M., \& Purves, R. S. (2005). Simulation of snow shielding corrections for cosmogenic nuclide surface exposure studies. Geomorphology, 64, 67-85.

SI-Hex (2014). Sismicité de la France métropolitaine sur la période 1962-2009. http://www.franceseisme.fr/sismicite.html, accessed May 25, 2016.

SisFrance (2016). Sismicité historique de la France- Métropole, http://www.sisfrance.net/donnees_dates.asp, accessed may 25, 2016.

Sponheuer, W. \& Karnik, V. (1964). Neue seismiche Skala. In W. Sponheuer (Ed.), Proceedings $7^{\text {th }}$ Symposium of the ESC, Jena 24-30 Sept. 1962 (pp. 69-76). Veröffentlichungen Zentralinstitut für Bodendynamik und Erdbebenforschung Jena der Deutschen Akademie der Wissenschaften, 7.

Stone, J. O. (2000). Air pressure and cosmogenic isotopes production. Jornal of Geophysical Research, 105(B10), 23753-23759.

Sue, C., Thouvenot, F., \& Fréchet, J. (1999). Widespread extension in the core of the western Alps revealed by earthquake analysis. Journal of Geophysical Research, 104(B11), 25611-25622.
Szirtes, S. (1909). Katalog der im Jahre 1905 registrierten seismischen Störungen. Publications du Bureau Central de l'Association Internationale de Sismologie, Série B Catalogue partie II, p.18, Strasbourg.

Thouvenot, F., Fréchet, J., Jenatton, L., \& Gamond, J.-F. (2003). The Belledone Border Fault: identification of an active seimic strikeslip fault in the western Alps. Geophysical Journal International, 155, 174-192.

Thouvenot, F., Fréchet, J., Tapponnier, P., Thomas, J.-C., Le Brun, B., Menard, G., et al. (1998). The Ml 5.3 Epagny (French Alps) earthquake of 1996 July 15: a long-awaited event on the Vuache Fault. Geophysical Journal International, 135, 876-892.

Vallot, C. (1939). Massif du Mont-Blanc/Chamonix-Sixt. Carte itinéraire à l'échelle de 1: 60000, Girard et Barrère editions, Paris.

Vaneck, J., Zatopek, A., Karnik, V., Kondorskaya, N. V., Riznichenko, Y. V., Savarensky, E. F., Soloviev, S. L., Shebalin, N.V. (1962). Standardization of magnitude scales. Bulletin of the Academy of Sciences of the USSR Geophysical Series 108-111.

Vernant, P., Hivert, F., Chéry, J., Steer, P., Cattin, R., \& Rigo, A. (2013). Erosion-induced isostatic rebound triggers extension in low convergent mountain ranges. Geology, 41, 467-470. doi:10. 1130/G33942.1. 